\title{
Melting Ice Caps and the Economic Impact of Opening the Northern Sea Route
}

Eddy Bekkers

Joseph F. Francois

Hugo Rojas-Romagosa 



\title{
Melting Ice Caps and the Economic Impact of Opening the Northern Sea Route
}

\author{
Eddy Bekkers ${ }^{1}$, Joseph F. Francois*2, and Hugo Rojas-Romagosa ${ }^{3}$ \\ ${ }^{1}$ University of Bern \\ ${ }^{2}$ University of Bern and CEPR \\ ${ }^{3} \mathrm{CPB}$ Netherlands Bureau for Economic Policy Analysis
}

May 2015

\begin{abstract}
A consequence of melting Arctic ice caps is the commercial viability of the Northern Sea Route, connecting North-East Asia with North-Western Europe. This will represent a sizeable reduction in shipping distances and a decrease in the average transportation days by around one-third compared to the currently used Southern Sea Route. We examine the economic impact of the opening of the Northern Sea Route in a multi-sector Eaton and Kortum model with intermediate linkages. This includes a remarkable shift of bilateral trade flows between Asia and Europe, diversion of trade within Europe, heavy shipping traffic in the Arctic, and a substantial drop in traffic through Suez. These global trade changes are reflected in real income and welfare effects for the countries involved. The estimated redirection of trade has also major geopolitical implications: the reorganisation of global supply chains within Europe and between Europe and Asia, and the highlighted political interest and environmental pressure on the Arctic.

Keywords: Northern Sea Route, trade forecasting, gravity model, CGE models, trade and emissions

JEL Classification: R4, F17, C2, D58, F18
\end{abstract}

\section{Introduction}

Arctic ice caps have been melting as a result of global warming (Kay et al., 2011; Day et al., 2012). The steady reduction of the Arctic sea ice has been well documented (Rodrigues, 2008, Kinnard et al., 2011, Comiso, 2012), and there is broad agreement on continued ice reductions through this century (Wang and Overland, 2009, 2012

\footnotetext{
*Corresponding author; e-mail: joseph.francois@gmail.com
} 
Vavrus et al. 2012) 1. Recent satellite observations, furthermore, suggest that the climate model simulations may be underestimating the melting rate (Kattsov et al. 2010: Rampal et al., 2011). This implies that in the recent future the extension of the Arctic ice caps will be greatly reduced and even completely ice-free during the summer. Besides the environmental effects, another consequence of this climatic phenomenon is the possibility of opening up the Northern Sea Route (NSR) for high volume commercial traffic. This shipping route will connect North East Asia (i.e. Japan, South Korea and China) with Northwestern Europe through the Arctic Ocean (see Figure 1). In practical terms, this represents a reduction in the average shipping distances and days of transportation by around one third with respect to the currently used Southern Sea Route (SSR). These reductions translate not only into fuel savings and overall transport costs, but also to significant transport time savings that may effectively force supply chains in industries between East Asia and Europe to change.

Figure 1: The NSR and SSR shipping routes

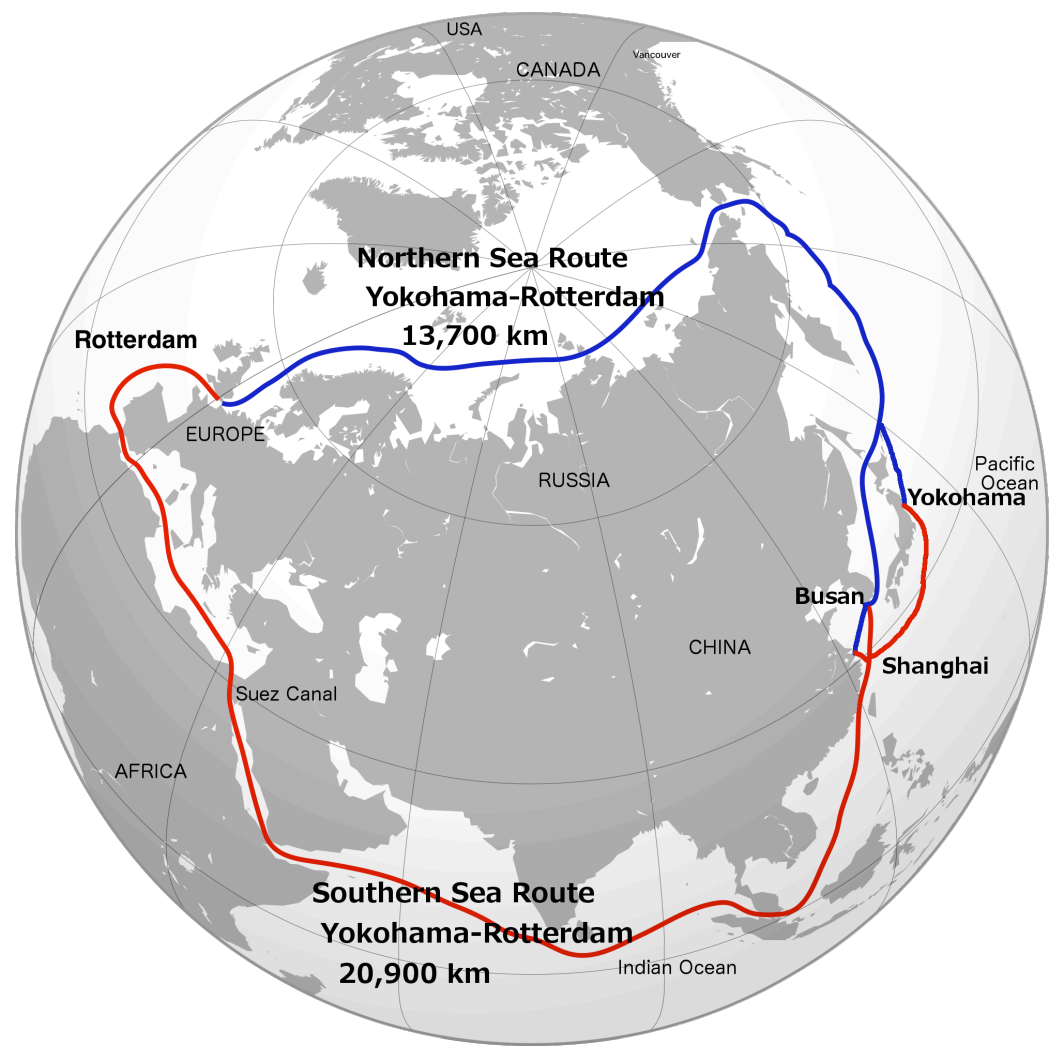

\footnotetext{
${ }^{1}$ The ice caps in Greenland and Antarctica have also been melting at an ever-quicker pace since 1992 (Shepherd et al., 2012 Kerr, 2012).
} 
The NSR is already open during summer and a number of ships have already used the route ${ }^{2}$ Until 2011, there was still controversy about the feasibility of the commercial use of the NSR. However, the ever-quicker melting pace found in several studies (Shepherd et al., 2012, Kerr, 2012, Stroeve et al., 2012, Slezak, 2013) has broadened the consensus in favour of its likely commercial use in the near future. A growing number of papers find that this shipping route could be fully operational for several months or all-year round at different points in the future (cf. Verny and Grigentin, 2009, Liu and Kronbak, 2010; Khon et al., 2010; Stephenson et al., 2013 Rogers et al., 2015) ? $^{3}$ As a consequence, there has been heightened economic interest on the NSR: Asia's largest exporters -Japan, South Korea and China- are already investing in ice-capable vessels, while Russia has plans to further develop this shipping lane (Astill, 2012). Accordingly, the NSR will also have concrete geopolitical implications, with an expected decline in the shipping transit through the Indian Ocean and the Suez Canal as well as an increased political interest in the Arctic. China in particular has already shown political interest in the Arctic by signing a free-trade agreement with Iceland in April 2013 and most recently -together with Japan and South Korea- it gained observer status on the Arctic Council.

Given the current uncertainties regarding the relation between the icecap melting pace and the transport logistic barriers associated with the NSR, it is hard to predict the year when the NSR will become fully operational. Throughout our study we use a what-if approach where we assume that by the year 2030 the icecaps have melted far enough and logistics issues related to navigating the Arctic have been resolved, so the NSR is fully operationally all year round ${ }^{4}$ In practical terms, this also implies that we use an "upper bound" scenario that assumes that the NSR becomes a perfect substitute for the SSR, and as such, all commercial shipping between North East Asia and Northern Europe will use the shorter and cheaper NSR instead of the SSR. Furthermore, since the opening of the NSR will be a gradual process that will take a number of years, the economic adjustment pattern we describe in our analysis will also be gradual.

Our economic analysis follows a three-step process. In the first step we recalculate physical distances between countries to account for water-transportation shipping routes. In the second step we map out a multi-sector general equilibrium model with intermediate linkages and trade modelled as in Eaton and Kortum (2002) and derive a gravity equation to structurally estimate the trade elasticities and to map the new distance calculations -for both the SSR and the NSR-into estimations

\footnotetext{
${ }^{2}$ These include recent shipping milestones: the fastest crossing Barents Observer $(2011 \mathrm{~b})$ and the first supertanker to use the NSR Barents Observer (2011a).

${ }^{3}$ The differences on the approximate year and the yearly extent for which the NSR will be fully operational varies much between papers, depending on different assumptions and estimations regarding the pace of the ice caps melting and developments in the shipping industry with respect to the new route.

${ }^{4}$ The use of 2030 as our benchmark year is mainly for illustration purposes and the use of another year does not affect our main economic results. For instance, we ran simulations using 2020 and 2050 as our benchmark year, and our main results remain robust to these changes.
} 
of the bilateral trade cost reductions between trading partners at the industry level. In the third step we simulate the effect of the commercial opening of the NSR on bilateral trade flows, macroeconomic outcomes, labour effects and changes in $\mathrm{CO} 2$ emissions employing our theoretical model.

With our model setup and calibration we are in the middle between the older computable general equilibrium (CGE) models (cf. Dixon and Jorgenson, 2013), and the recent quantitative trade models (see Costinot and Rodríguez-Clare, 2013, for an overview). The interaction of both analytical frameworks generates important synergies. For instance, following the new quantitative trade models we improve the CGE estimations in two fundamental ways. First, we model trade linkages with the improved micro-founded Eaton and Kortum (2002) structure. Second, we structurally estimate the trade parameters employing a gravity model derived from the theoretical model using the same trade data that is used in numerical simulations. On the other hand, we retain important elements of CGE modelling that are not present in the new quantitative trade models. First, we work with a detailed and consistent dataset for multi-sectors and countries with trade costs that explicitly include export taxes, international transport costs and import tariffs varying by country-pairs and sectors. Such a detailed break-down of overall trade costs is not present in recent quantitative trade models 5 Second, we use a richer general equilibrium framework that includes non-homothetic preferences, accounts for government expenditures, overall savings and investment, multiple factors of production with varying degrees of mobility, and linkages to emissions data. Thus, our model is a large multi-sector implementation of an Eaton-Kortum model embedded in a CGE framework, where we use econometric estimations of the Eaton-Kortum derived gravity equation to parameterise the key trade and demand equations in the CGE model.

The NSR reduces shipping distances and time between Northwestern Europe and Northeast Asia by about one third. These overall trade cost reductions can further be separated between actual shipping cost reductions (i.e. fuel savings and other transport costs) and distance-related iceberg trade costs (e.g. transport time savings that can effectively create new supply chains in certain industries). We find average transport cost reductions of between $20 \%$ and $30 \%$ between both regions using intensively the NSR, while iceberg trade cost reductions are estimated to be around $3 \%$ of the value of goods sold.

Using our model, we find that the direct consequence of opening-up the NSR is that international shipping (volume by distance) is reduced by $0.43 \%$, but global trade volumes increase by $0.21 \%$. Although global trade volume changes are not radically high, they are completely concentrated in trade increases that average around $10 \%$ between Northeast Asia (i.e. China, Japan and South Korea) and Northwestern Europe. We estimate that the share of World trade that is re-routed through the

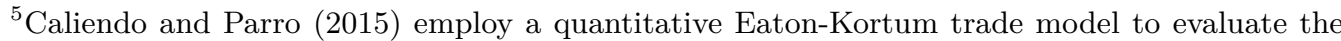
effect of NAFTA, arguing against the use of CGE-models claiming that they are too much a black box. By clearly mapping out the structure of our model, we do not consider our model specification to be a black box. Furthermore, the detailed break-down of trade costs is essential for our analysis of the NSR.
} 
NSR will be of $5.5 \%$. For instance, $15 \%$ of Chinese trade will use the NSR in the future. This will result in a massive shift of shipping tonnage from the currently used SSR to the NSR. Roughly $8 \%$ of World trade is currently transported through the Suez Canal, and we estimate that this share would drop by around two-thirds with a re-routing of trade over the shorter Arctic route. Since on average around 15,000 commercial ships crossed the Suez Canal yearly between 2008 and 2012, the re-routing of ships through the NSR will represent about 10,000 ships crossing the Arctic yearly: ${ }^{6}$ This implies incentives for large-scale construction of physical infrastructure in sensitive Arctic ecosystems, heightened economic security interests linked to Arctic trade, and tremendous pressure on the facilities and economies servicing the older SSR (including Egypt and Singapore).

This huge increase in bilateral trade between these two relatively large economic zones also results in a significant diversion of trade. The bilateral trade flows between Northeast Asia and Northwestern Europe significantly increase at the expense of less trade with other regions. In particular, there is a sizeable reduction in intra-European trade, with less trade between Northwestern Europe with South and Eastern Europe. Bilateral exports from Northwestern Europe (Germany, France, The Netherlands and the UK) to/from Northeastern Asia (China, Japan and South Korea) increase significantly, while South European exports remain unchanged. The Eastern countries of the EU experience a combination of dramatic increases in exports to Asia (e.g. Poland and Czech Republic) with no significant changes in exports for Hungary and Romania.

The changing opportunities for trade translate into macroeconomic impacts as well: real incomes and GDP are estimated to increase modestly in the countries that benefit directly from the NSR. Northeast Asia and Northwestern Europe experiences the biggest gains. On the other hand, most South and Eastern European countries experience real income decreases. Hence, the disruption in intra-EU trade and regional production value chains caused by the opening of the NSR, is negatively affecting the South and Eastern EU member states. For the affected countries, these impacts -in the range of less than half a percentage point of GDP- are comparable to estimated effects from an EU-US free trade agreement, or the Doha and Uruguay Rounds of multilateral trade negotiations.7.$^{7}$ Moreover, there are small labour market effects at the aggregate and sectoral level, so there is relatively little labour displacement effects, which will not represent an important shock.

Finally, we also estimate the impact of the NSR on changes in CO2 emissions. We find that although the much shorter shipping distances will reduce the emissions associated with water transport, these gains are all but offset by a combination of higher volumes traded between Northeast Asia and Northwestern Europe, and a shift in emission-intensive production to East Asia.

The paper is organised as follows. In Section 2 we analyse the logistic issues and projections for commercially using the NSR in the future. We then explain how we

\footnotetext{
${ }^{6}$ Transit data are available from the Suez Canal Authority (http://www.suezcanal.gov.eg).

${ }^{7}$ See for example Francois (2000), Francois et al. (2005), and Francois et al. (2013).
} 
estimate the new water-transportation distances in Section 3. In the next section we map out the theoretical structure to evaluate the impact of the NSR. In section 5 we discuss calibration of the model, derive a gravity equation and estimate the gravity equation to calculate the effect of the new distance measures on trade costs. The simulations and macroeconomic results are presented in Section 6. Section 7 concludes by summarising our main results.

\section{Commercial feasibility of the Northern Sea Route}

There are two elements that condition the NSR becoming a fully viable commercial substitute of the SSR. The first is the ice levels in the Arctic, which is the main barrier to the commercial use of the NSR. As mentioned before, there is ample scientific evidence of the melting of the Arctic ice cap (Rodrigues, 2008, Kinnard et al., 2011; Comiso, 2012), that it will continue melting in the future (Wang and Overland, 2009, 2012; Vavrus et al., 2012), and other studies even suggest that the melting process may accelerate in the future as well (Kattsov et al., 2010, Rampal et al., 2011). Stammerjohn et al. (2012) note that already some Arctic regions are ice free now more than predicted by climate models for 2030, while in a meta-analysis of model results Rogers et al. (2015) identify a median prediction of 2034 for an ice free Arctic in September. These elements will make the commercial use of the NSR more likely in the near future. Figure 2 further illustrates the current degree of ice cap melting (until 2007) and the forecasts produced by the GFDL model of the National Oceanic and Atmospheric Administration (NOAA). From this figure one can observe that by 2030 the ice cap will have melted enough to make the NSR ice-free, although it is not clear if this will be the prevalent condition year-round by then. These predictions have been also supported by more recent research (Wang and Overland, 2012).

The second barrier to the NSR is the transport logistic issues associated with the opening of a new commercial shipping route in a region with extreme weather conditions. Even though a number of ships have already used the NSR during summer months, significant logistical obstacles remain. These include slower speeds, Russian fees and customs clearance, limited commercial weather forecasts, patchy search and rescue capabilities, scarcity of relief ports along the route and the need to use icebreakers and/or ice-capable vessels (Liu and Kronbak, 2010; Schøyen and Bråthen, 2011). These conditions not only affect the insurance premia currently charged to use the NSR, but also they limit the commercial viability of shipping operations, which are dependent on predictability, punctuality and economies of scale (Humpert and Raspotnik, 2012). However, with a yearly increasing number of ships using the NSR and the political and economic interest of Russia and other stakeholders to develop the NSR, it is expected that these logistic limitations will be gradually overcome in the near future ${ }^{8}$

\footnotetext{
${ }^{8}$ For instance, Russia created a Federal State Institution in March 2013 to administrate the NSR: The Northern Sea Route Administration (www.nsra.ru), which provides logistical assistance
} 
Figure 2: Arctic Sea Ice Extent observation (1970 to 2007) and forecast (2030 to 2100)

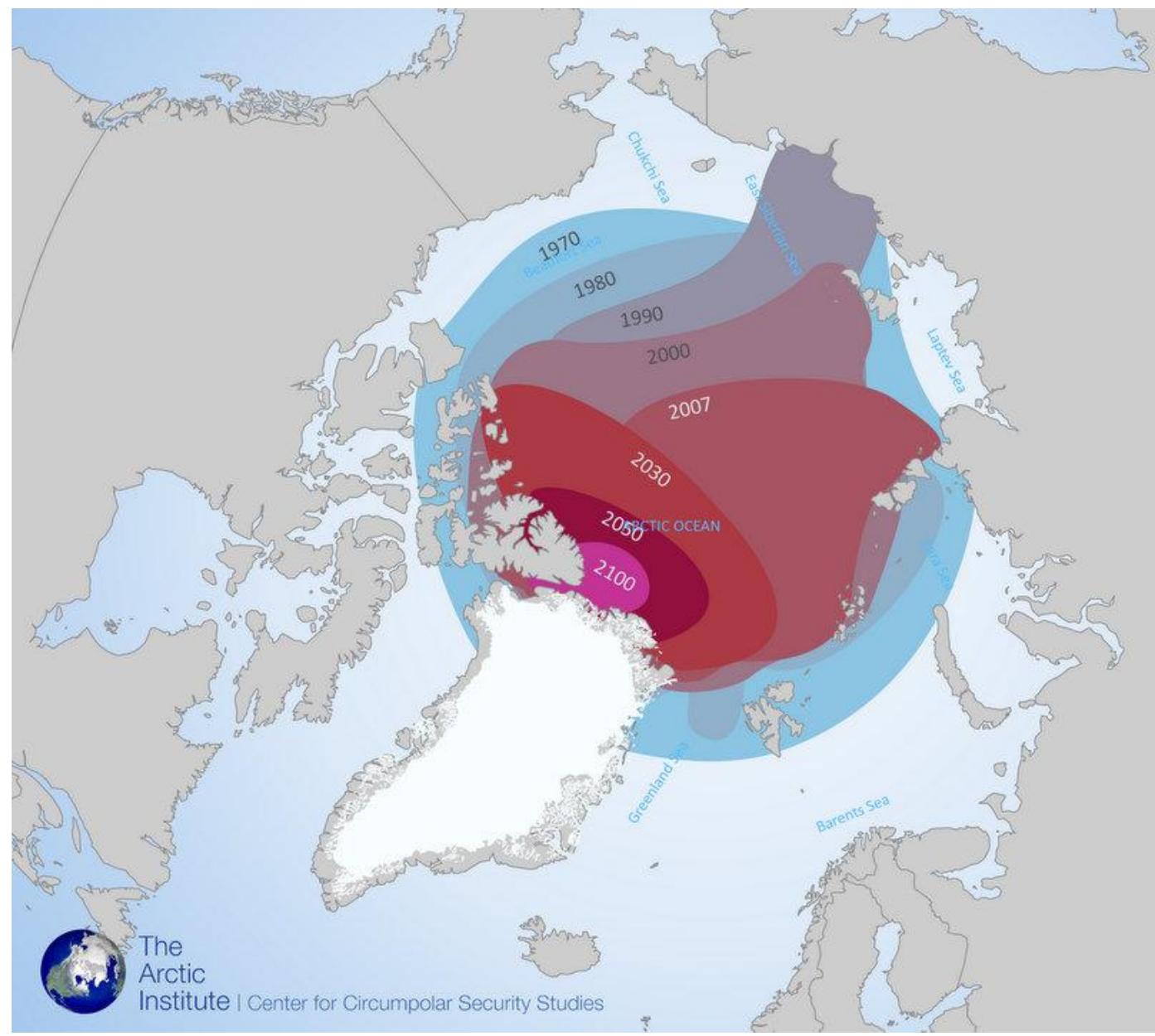

Source: NOAA GFDL model reproduced in Humpert and Raspotnik (2012) by The Arctic

$$
\text { Institute. }
$$

The uncertainties of both the pace and extent of ice cap melting and the logistical conditions associated with a fully commercial use of the NSR are translated into a wide range of estimates regarding the precise date when the NSR will be fully operational. The uncertainties regarding both elements, are also directly related and reinforce each other. In particular, a quicker pace of melting will also make it easier to overcome the transport logistical obstacles. Therefore, the assessments of the feasibility of the NSR range from studies that see limited use of the NSR for many years to come (cf. Lasserre and Pelletier, 2011, and papers referred therein)

throughout the route. In addition, Russia has also already started setting up 10 relief ports along the route. 
and more optimistic papers that foresee the commercial use of the NSR within 10 years (Verny and Grigentin, 2009).

In our study, we take a middle-point approach and use 2030 as our benchmark year, for which we assume that the NSR will be fully operational all-year round. However, our economic estimations are not dependent on this occurring precisely in 2030. We needed to choose a benchmark year mainly for reporting reasons, since we expect to have quantitatively similar results if we used another benchmark year, either an earlier one (2020) or later one (2050) $?^{9}$

The main fact needed for our estimations to be relevant, however, is that the NSR must become (at some point in time) fully commercially viable during the whole year, so it is in practical terms, a fully viable (and perfect) substitute to the SSR. This implies that we use an "upper bound" scenario that will estimate the largest expected trade and economic impact from the NSR. 10

It is important to note that the melting of the Arctic icecaps will be a global climate phenomenon with widespread ecological and economic impacts. From the economic point of view, the opening of the NSR will be one of the main impacts, but not the only one. Additional economic impacts may include the possibility to exploit natural resources in the Arctic Ocean and the Arctic region (i.e. Siberia and Northern Scandinavia), and the potential opening of the North Western Route connecting Northeast Asia with the East Coast of Canada and the United States.

\section{Estimating shipping distance reductions using the North- ern Sea Route}

As the first step of our analysis, we estimate the precise distance reductions for bilateral trade flows associated with the NSR. To do so we first need to include shipping routes in the estimation of the distance between two trading partners. Currently, the econometric literature on the gravity model of bilateral trade relies on measures of physical distances between national capitals as a measure of distance, known as the CEPII database (Mayer and Zignago, 2011).11 However, these measures use the

\footnotetext{
${ }^{9}$ As a robustness analysis, we use these two different years as our benchmarks: 2020 and 2050. Our results show that the use of different benchmark years affects the size of some of the results, but the main qualitative results and patterns describe for 2030 remain robust to the use of different years. The results fro 2020 and 2050 are available upon request.

${ }^{10}$ For instance, if the NSR is not operational during winter and/or other logistic issues related to the extreme weather of the Arctic are not fully resolved, then it can be expected that shipping companies pursue a diversification strategy, using both routes conditional on which offers the lowest costs at certain seasons the year. Another potential limitation of the NSR fully substituting the SSR is the increased pressure on current transportation infrastructure. In particular, current hubs -i.e. the Port of Rotterdam- may need to expand. However, since the opening of the NSR will be a gradual process, we expect that any additional infrastructure needs can be developed while the NSR becomes fully operational.

${ }^{11}$ In particular, CEPII's GeoDist database (www.cepii.fr) estimates geodesic distances, which are calculated using the geographic coordinates of the capital cities. A simple measure is the distance between countries' capitals on the surface of a sphere (i.e. the great-circle formula). A
} 
shortest physical distance and thus, are not appropriate for the present exercise. Shipping routes are usually longer than the shortest physical distance, and melting sea ice will not change the physical distance between Tokyo and London, for example.

\subsection{Current shipping distances}

Rather we need a more precise measure of actual shipping distances. To this end, we first build a new measure of distance between trading countries. Given the importance of ocean transport for global trade we wanted to take water distances between trading partners into account. Globally, $90 \%$ of world trade in volume and $80 \%$ in value -and the overwhelming majority of trade between non-neighbouring countries- is carried by ship (OECD, 2011, 2013), 12 For the country pairs and trade flows we focus on here, water transportation, or multi-modal transport (water and land) accounts for a majority of trade.

Therefore, to obtain more accurate measures of trade distance, we work with shipping industry data on the physical distance of shipping routes between ports in combination with land-transport distances. We continue to use CEPII's bilateral distances to represent land routes (and so the land component of combined landwater routes), while the water routes were provided by AtoBviaC. ${ }^{13}$ As water routes we define the shortest water distances between two major ports. For each country we choose one major port. As a country's major port we define the largest and/or most significant port in terms of tons of cargo per year from ocean-going ships except for Australia, Canada, Spain, France, Great Britain, India, Russia, United States, and South Africa, where due to the large size of these countries and their multiple accesses to water we picked two or, in the case of the US, three major ports. In the case of two trading partners with access to water, distance is calculated as the shortest land and water distance between these countries' major ports. For example we estimate the trade distance between China and The Netherlands as the shipping distance from Shanghai to Rotterdam using either the SSR or the NSR. For landlocked countries ${ }^{14}$ we assume that a port in a neighbouring country is used,

more recent and sophisticated approach is to measure distance between two countries using the population weighted average index created by (Head and Mayer, 2010, de Sousa et al., 2012). This last measure also incorporates the internal distances of a country.

${ }^{12}$ The rest moves primarily by land. Few exceptions use air transportation, which mainly applies for high-value commodities that need to reach the final destination in a short time (e.g. fish and flowers).

${ }^{13}$ This is a commercial company that offers sea distances to the maritime industry (www.atobviaconline.com/public/default.aspx). In particular, they provided us with port-to-port water distances.

${ }^{14}$ These are countries that do not have direct access to an ocean or an ocean-accessible water way, and thus must rely upon neighbouring countries for access to seaports. Landlocked countries in our dataset are Afghanistan, Andorra, Armenia, Austria, Azerbaijan, Belarus, Bhutan, Bolivia, Botswana, Burkina Faso, Burundi, Central African Republic, Chad, Czech Republic, Ethiopia, Hungary, Kazakhstan, Kyrgyzstan, Kosovo, Laos, Lesotho, Liechtenstein, Luxembourg, Republic of Macedonia, Malawi, Mali, Moldova, Mongolia, Nepal, Niger, Paraguay, Rwanda, San Marino, 
so distance between a landlocked country and a trading partner with access to water is obtained by combining the landlocked country's land distance (from CEPII) to a neighbouring country with a major port and water distances from that port to different trading partners (from AtoBviaC). For example distance between Austria and Nepal (both landlocked) is obtained as a combination of land distance from Austria to Germany, water distance from Germany to India, and land distance from India to Nepal.

Finally, we also take into account shipping distance asymmetries. Due to sea currents, commercial shipping lanes, anti-piracy routes and country specific seafaring regulations, shipping distances from country A to country B are not the same as the distance from B to A. Hence there are asymmetries in shipping distances, which can represent up to two percentage-points differences in the distance reductions using the SSR.

\subsection{New shipping distances using the NSR}

For the new distances related to the opening up of the NSR, we use the estimates by Liu and Kronbak (2010) 15 Since only some countries will experiment shorter shipping distances with the opening of the NSR, we estimate the new shorter distances to Europe for a selected number of Asian and Oceanian countries. ${ }^{16}$ Thus, we also estimated the new distances between all European countries and the selected countries above.

In Table 1 we show the great-circle formula distances, current shipping distances (using the SSR), the new NSR distances and the percentage reductions between Northeast Asia's biggest exporters (China, Japan, South Korea and Taiwan) and the four Northern European countries with the busiest container ports: Netherlands (Rotterdam), Belgium (Antwerpen), Germany (Hamburg and Bremerhaven) and Great Britain (Felixstowe). The commercial use of the NSR implies a significant shipping distance reduction. For instance, the effective distance is reduced by around $37 \%$ from Japan to North European countries, while the same figure is around $31 \%$ for South Korea, $23 \%$ for China and $17 \%$ for Taiwan.

Serbia, Slovakia, Swaziland, Switzerland, Tajikistan, Turkmenistan, Uganda, Uzbekistan, Vatican City, Zambia, Zimbabwe.

${ }^{15}$ They estimate that the distance reduction between Yokohama and Rotterdam using the NSR will be of $8075 \mathrm{~km}$. We then adjust for the distance Yokohama-Nagoya $(251 \mathrm{~km})$ to get the NagoyaRotterdam reduction $(7824 \mathrm{~km})$, which is comparable to the AtoBviaC SSR distance NagoyaRotterdam. For European countries south of Rotterdam we use the AtoBviaC distances between those ports to Rotterdam and then the Rotterdam-Nagoya NSR distance and then the distance from Nagoya to other Asian countries. For European countries north of Rotterdam we use the BLM Shipping 2.0 software to obtain the distance from Troms $\varnothing$ (Norway) to Rotterdam, and then estimate the distance Troms $\varnothing$-Nagoya using the NSR. Then we use shipping distances from North European ports to Troms $\varnothing$ to obtain their NSR distances to Japan and the other Asian countries.

${ }^{16}$ These are: Japan, North and South Korea, China, Hong Kong, Taiwan, Singapore, Viet Nam, Cambodia, Philippines, Indonesia, Malaysia, Thailand, Papua New Guinea, Australia and New Zealand. 
Table 1: Different distance values for selected countries

\begin{tabular}{|c|c|c|c|c|c|}
\hline From: & To: & $\begin{array}{l}\text { Great-circle } \\
\text { formula }(\mathrm{km})\end{array}$ & SSR $(\mathrm{km})$ & NSR $(\mathrm{km})$ & $\begin{array}{l}\text { NSR against } \\
\text { SSR \% change }\end{array}$ \\
\hline China & Netherlands & 7,831 & 19,942 & 15,436 & $-23 \%$ \\
\hline China & Belgium & 7,971 & 19,914 & 15,477 & $-22 \%$ \\
\hline China & Germany & 7,363 & 20,478 & 15,942 & $-22 \%$ \\
\hline China & United Kingdom & 8,151 & 19,799 & 14,898 & $-25 \%$ \\
\hline Japan & Netherlands & 9,303 & 20,996 & 13,172 & $-37 \%$ \\
\hline Japan & Belgium & 9,464 & 20,976 & 13,345 & $-36 \%$ \\
\hline Japan & Germany & 8,928 & 21,536 & 13,083 & $-39 \%$ \\
\hline Japan & United Kingdom & 9,574 & 20,779 & 13,182 & $-37 \%$ \\
\hline South Korea & Netherlands & 8,573 & 20,479 & 14,200 & $-31 \%$ \\
\hline South Korea & Belgium & 8,722 & 20,458 & 14,373 & $-30 \%$ \\
\hline South Korea & Germany & 8,140 & 21,019 & 14,110 & $-33 \%$ \\
\hline South Korea & United Kingdom & 8,875 & 20,262 & 14,210 & $-30 \%$ \\
\hline Taiwan & Netherlands & 9,457 & 18,822 & 15,601 & $-17 \%$ \\
\hline Taiwan & Belgium & 9,587 & 18,801 & 15,774 & $-16 \%$ \\
\hline Taiwan & Germany & 8,959 & 19,362 & 15,511 & $-20 \%$ \\
\hline Taiwan & United Kingdom & 9,790 & 18,605 & 15,611 & $-16 \%$ \\
\hline
\end{tabular}

Sources: Great-circle distances taken from the GeoDist database from CEPII. SSR and NSR distances are own estimations based on data from AtoBviaC, BLM Shipping, and Liu and Kronbak (2010).

It is important to note that the NSR only makes the shipping distance shorter for countries in northern East Asia, but not for countries closer or below to the equator. For instance, the shipping distances from the Philippines and Papua New Guinea to Northern Europe are slightly shorter using the NSR (by around $1500 \mathrm{~km}$ ), but countries that are located South and East from these countries have shorter shipping distances using the SSR (e.g. Viet Nam, Thailand, Singapore, Indonesia, Malaysia, India).

\section{Model}

Since the opening of the NSR is a global phenomenon that affects several countries at once, it will create inter-related shocks between different trading economies. Trade facilitation through the NSR will not only affect bilateral trade, but also sectoral production and consumption patterns, relative domestic and international prices and the way production factors are used in different countries. Therefore, we employ a general equilibrium model with multiple countries, multiple sectors with intermediate linkages, and multiple factors of production. Trade is modelled as in Eaton 
and Kortum (2002) with the remaining structure of the model largely following the standard GTAP CGE model (Hertel, 2013).

\subsection{General structure}

Due to space constraints we assume that the reader is familiar with conventional production functions like Cobb-Douglas, CES and Leontief. There are $J=110$ countries. In each country $j$ utility is a Cobb-Douglas function over three aggregate goods, private goods $q_{j}^{p}$, public goods $q_{j}^{g}$, and savings $q_{j}^{s}$. Preferences for private goods in turn are described by the non-homothetic Constant Distance Elasticity (CDE) function over 16 sectors $s$. With CDE preferences the model allows for shifting average and marginal budget shares as a country grows. At the same time the model stays tractable in a setting with a large number of countries and sectors, since a limited number of parameters can be calibrated from income and own-price elasticities of demand. CDE preferences can be described by the following implicit expenditure function:

$$
\sum_{s=1}^{S} \alpha_{j s}\left(q_{j}^{p}\right)^{\gamma_{j s} \eta_{j s}}\left(\frac{p_{j s}^{p}}{x_{j}^{p}}\right)^{\gamma_{j s}}=1
$$

where $p_{j s}^{p}$ is the price of private goods in country $j$ and sector $s, x_{j}^{p}$ are private expenditures in country $j$ and $\alpha_{j s}, \gamma_{j s}$ and $\eta_{j s}$ are parameters (called respectively the distribution, substitution and expansion parameters). Demand $q_{j s}^{p}$ follows from log-differentiating equation (1) with respect to $p_{j s}^{p}$ and $x_{j}^{p}$, and reorganising we obtain:

$$
q_{j s}^{p}=\frac{\alpha_{j s}\left(q_{j}^{p}\right)^{\gamma_{j s} \eta_{j s}}\left(\frac{p_{j s}^{p}}{x_{j}^{p}}\right)^{\gamma_{j s}-1} \gamma_{j s}}{\sum_{u=1}^{S} \alpha_{j u}\left(q_{j}^{p}\right)^{\gamma_{j u} \eta_{j u}}\left(\frac{p_{j u}^{p}}{x_{j}^{p}}\right)^{\gamma_{j u}} \gamma_{j u}}
$$

Preferences for spending by the public sector across the 16 sectors are CES. Including savings in the static utility function implies that a shift away from future consumption and savings towards current consumption would have large welfare effects. The formal underpinning comes from Hanoch (1975) who showed that the expressions for consumption in an inter-temporal setting can also be derived from a static utility maximisation problem with savings in the utility function. Savings are used to finance investments. Savings in all countries are collected by a "global bank" channeling the savings to investment in different countries with an incentive to invest more in countries with a higher rate of return. Rates of return are not equalised in the model, though, to prevent large swings in investment demand.

\subsection{International trade}

Within each of the 16 sectors production takes place as in Eaton and Kortum (2002). So there is a continuum of varieties each country can produce under perfect competition with consumers having a CES utility function across the continuum. The 
cost of delivering a variety from source $i$ to destination $j$ in sector $s$ is given by:

$$
p_{i j s}=\frac{c_{i s} t_{i j s}}{z}
$$

where $c_{i s}$ is the price of input bundles in country $i$ and sector $s$ and $t_{i j s}$ is the composite of trade costs expressed in power terms. The productivity $z$ is drawn from a Frechet distribution with technology parameter $z_{i s}$ and dispersion parameter $\theta_{s}$, as:

$$
P\left(z_{i s} \leq z\right)=\exp \left(-\left(\frac{z}{z_{i s}}\right)^{-\theta_{s}}\right)
$$

Composite trade costs $t_{i j s}$ consist of one plus the export tax $e t_{i j s}$, one plus the international transport margin $i t m_{i j s}$, one plus the import tariff $t a_{i j s}$, and iceberg trade costs $\tau_{i j s}$, which in turn consists of an observable component $\bar{\tau}_{i j s}$ driven by gravity type variables and an unobservable component $\widetilde{\tau}_{i j s}$, such that:

$$
t_{i j s}=\left(1+e t_{i j s}\right)\left(1+i t m_{i j s}\right)\left(1+t a_{i j s}\right) \bar{\tau}_{i j s} \widetilde{\tau}_{i j s}
$$

Because of the detailed GTAP-data we can include also export taxes and international transport margins as components of trade costs. This is an important improvement on previous Eaton-Kortum multi-sector applications and it allows us to explicitly model international transport costs and how they are affected by the NSR.

The international transport margin $i t m_{i j s}$ is equal to payments to the value of international transport services $v i t s_{i j s}$ divided by the FOB value of trade $v_{i j s}^{f o b}$. The demand for international transport services is proportional to the demand for export goods. International transport services are supplied by all countries and aggregated into global transport services by a Cobb-Douglas production function 17

$c_{i s}$ is the price of input bundles used for production in country $i$ and sector $s$, determined by the price of intermediates used from all sectors and the price of factor input bundles. The choice between the aggregates of intermediates and factor inputs is described by a Leontief production function. Also the choice between intermediates from different sectors is Leontief. There are five different factor inputs: land, unskilled and skilled labour, capital, and natural resources. The choice between factor input bundles is CES. Land and natural resources are not perfectly mobile between sectors, and are modelled by an elasticity of transformation function.

With our setup the quantity sold from $i$ to $j$ at the sectoral level, $q_{i j s}$, is given by:

$$
q_{i j s}=\frac{\left(\frac{c_{i s}}{z_{i s}} t_{i j s}\right)^{-\theta_{s}} q_{j s}}{\sum_{k=1}^{J}\left(\frac{c_{k s}}{z_{k s}} t_{k j s}\right)^{-\theta_{s}}}
$$

\footnotetext{
${ }^{17}$ Due to a lack of data there is no link between the supplying country and the demanding countries of these services.
} 
$q_{j s}$ is the total demand for goods in sector $s$ in country $j$, reflecting demand for intermediates by firms, demand for capital goods, and demand for public and private goods. A reduction in trade costs as a result of for example the NSR generates both more trade along the intensive and the extensive margin in the model. With lower trade costs there are more sales of each variety within a sector and more varieties are sold.

Eaton and Kortum (2002) only express the value of sales. We work with quantities, since our numerical model is expressed in quantities. Because the price distribution in country $j$ of goods bought from country $i$ is identical for all sources $i$ (property $b$ on page 1748 of Eaton and Kortum, 2002), the quantity share is identical to the volume share in the Eaton and Kortum model.

\section{Calibration of the model}

\subsection{Gravity estimation of trade parameters}

The trade parameters required to implement the model numerically are the dispersion parameters $\theta_{s}$, the technology parameters $z_{i s}$ and the trade costs $t_{i j s}$. To obtain the dispersion parameters we estimate a gravity equation following from the theoretical structure with Eaton and Kortum production. The expression for the value of trade $v_{i j s}$ is identical to the expression for the quantity of trade in equation (6), except for the fact that the total quantity demanded $q_{j s}$ is replaced by the total value demanded. Capturing $\left(\frac{c_{i s}}{z_{i s}}\right)^{-\theta}$ by an exporter fixed effect $d_{i s}$ and the value demanded by an importer-fixed effect $d_{j s}$ and dividing by one plus the import tariff gives the following gravity equation for the value of trade $v_{i j s}$ in CIF terms 18

$$
\ln v_{i j s}^{c i f}=d_{i s}+d_{j s}-\left(\theta_{s}+1\right) \ln \left(1+t a_{i j s}\right)\left(1+i t m_{i j s}\right)+\beta_{s} \ln x_{i j s}+\varepsilon_{i j s}
$$

where $x_{i j s}$ consists of observable variables explaining iceberg trade $\operatorname{costs} \tau_{i j s}$ (and the export tax $\left.e t_{i j s}\right)$. As observable variables we include the standard gravity variables: distance, common colony, common language, common border (contiguous), former colony and dummies for shallow, medium and deep free trade agreements (FTA) ${ }^{19}$ Preferential trade agreements are free trade agreements and customs unions that have been agreed at least four years previously (Dür et al. 2014). Besides these traditional gravity regressors, we include two political economy variables, $\mathrm{PE}$ index 1 and PE index 2, measuring the pairwise similarity of the two trading partners. These variables reflect evidence that homophily is important in explaining direct economic and political linkages (De Benedictis and Tajoli, 2011). The two political

\footnotetext{
${ }^{18}$ The value of trade in our theoretical model is inclusive of tariffs paid. So to get the value of trade in CIF terms, thus excluding the import tariff, we divide by one plus the import tariff.

${ }^{19}$ Following Egger et al. (2011), we instrument preferential trade agreements. As explanatory variables in the first stage regression we include the variables also present in the gravity equation (except for tariffs) as well as lagged trade network embeddedness (Easley and Kleinberg, 2010, De Benedictis and Tajoli, 2011, Zhou, 2011) and a variable for the economic mass of the two trading partners together, measured as GDP of the source country times GDP of the destination country.
} 
economy variables are calculated as the two first principal components of the following four variables: the difference in polity, the functioning of governance difference, the corruption score difference, and the difference in civil society scores.

Following the theoretical gravity equation, tariffs and the international transport margin have the same coefficient and are thus included as one combined variable, $\ln \left(1+t a_{i j s}\right)\left(1+i t m_{i j s}\right)$, called Trade Cost in Table 2. As tariff variable $\ln \left(1+t a_{i j s}\right)$ we employ the log difference between the most favoured nation (MFN) tariff rate and the preferential tariff rate (based on FTAs), with the MFN rate also captured by the importer fixed effect. Data on the international transport margin are taken from the GTAP database. Since data on transport margins are only available for a limited number of countries, we use fitted values for the missing observations on the transport margin from a regression of transport margins on the same set of explanatory variables as those used in the gravity equation (excluding tariffs).

We estimate equation (7) using a sample of 110 countries in 2011. Trade data are taken from the GTAP database to have consistency with the CGE simulations ${ }^{20}$ Data for tariffs come from the World Bank/UNCTAD WITS database. Distance data, as discussed above, are based on the length of shipping routes. Other socioeconomic data are from Dür et al. (2014), the CEPII database (Mayer and Zignago, 2011), and the Quality of Governance (QoG) expert survey dataset (Teorell et al. 2011). Following Santos Silva and Tenreyro (2006, 2011), we estimate equation (7) with Poisson pseudo-maximum likelihood (PPML) for trade for each manufacturing sector in the computational model. 21

The results are shown in Table 2. The tariff elasticities give us one plus the dispersion parameters $\theta_{s}$. The distance elasticities will be used to calculate the total trade cost reductions as a result of the reduction in shipping distances. Since we cannot estimate tariff elasticities for the services sector, we use the trade elasticities employed in the GTAP model implying a value of 2.8 for the dispersion parameters.

To shed light on the importance of changes in shipping distance, we explore how much the variation in distance contributes to the variation in trade flows. We do this in two ways. First, we show that distance explains between $3 \%$ and $19 \%$ of the variation in trade flows in the different sectors with all control variables (see the last row of Table 2). Second, due to multicollinearity with variables like FTA, we have also evaluated the change in the pseudo-R2 at the sectoral level when including distance in a regression of trade values with only importer and exporter fixed effects (see Table 7 in the Appendix). This exercise shows that including distance makes a huge difference, raising the $\mathrm{R} 2$ by $18 \%$ to $53 \%$ in the different sectors. So the change in shipping distance as a result of the NSR is an important factor to explain variation in trade flows.

The conventional approach to obtain trade costs $t_{i j s}$ and the technology parameters $z_{i s}$ in the Eaton and Kortum model starts with estimation of a gravity equation as in equation (7). Trade costs are equal to the fitted trade values based on the

\footnotetext{
${ }^{20}$ Using COMTRADE data gives almost exactly the same coefficient estimates.

${ }^{21}$ The 16 sectors are composed of 11 manufacturing sectors and 5 services sectors.
} 
Table 2: PPML gravity estimates for manufacturing sectors

\begin{tabular}{|c|c|c|c|c|c|c|c|c|c|c|c|}
\hline & $\mathrm{BT}$ & CRP & ELE & MTL & $\mathrm{MVH}$ & OGD & $\mathrm{OMC}$ & PRA & PRE & PRF & $\mathrm{P} \_\mathrm{C}$ \\
\hline trade costs & $\begin{array}{l}-1.700 \\
(3.29)^{* * *}\end{array}$ & $\begin{array}{l}-5.546 \\
(5.48)^{* * *}\end{array}$ & $\begin{array}{c}-13.489 \\
(4.93)^{* * *}\end{array}$ & $\begin{array}{l}-7.945 \\
(6.17)^{* * *}\end{array}$ & $\begin{array}{l}-3.396 \\
(2.96)^{* * *}\end{array}$ & $\begin{array}{l}-5.485 \\
(6.08)^{* * *}\end{array}$ & $\begin{array}{c}-13.940 \\
(7.45)^{* * *}\end{array}$ & $\begin{array}{l}-3.724 \\
(3.63)^{* * *}\end{array}$ & $\begin{array}{l}-6.483 \\
(10.25)^{* * *}\end{array}$ & $\begin{array}{l}-3.360 \\
(3.77)^{* * *}\end{array}$ & $\begin{array}{l}-11.386 \\
(4.10)^{* * *}\end{array}$ \\
\hline $\ln ($ distance $)$ & $\begin{array}{l}-0.665 \\
(31.02)^{* * *}\end{array}$ & $\begin{array}{c}-0.422 \\
(21.68)^{* * *}\end{array}$ & $\begin{array}{c}-0.394 \\
(16.42)^{* * *}\end{array}$ & $\begin{array}{c}-0.491 \\
(26.56)^{* * *}\end{array}$ & $\begin{array}{c}-0.464 \\
(18.78)^{* * *}\end{array}$ & $\begin{array}{c}-0.585 \\
(25.27)^{* * *}\end{array}$ & $\begin{array}{c}-0.348 \\
(18.53)^{* * *}\end{array}$ & $\begin{array}{c}-0.712 \\
(32.81)^{* * *}\end{array}$ & $\begin{array}{c}-0.604 \\
(35.10)^{* * * *}\end{array}$ & $\begin{array}{c}-0.609 \\
(22.54)^{* * *}\end{array}$ & $\begin{array}{c}-0.591 \\
(14.19)^{* * *}\end{array}$ \\
\hline PE index 1 & $\begin{array}{l}-0.237 \\
(5.39)^{* * *}\end{array}$ & $\begin{array}{c}0.004 \\
(0.16)\end{array}$ & $\begin{array}{c}0.239 \\
(6.13)^{* * *}\end{array}$ & $\begin{array}{l}0.047 \\
(1.97)^{* *}\end{array}$ & $\begin{array}{c}-0.035 \\
(0.78)\end{array}$ & $\begin{array}{c}0.169 \\
(5.74)^{* * *}\end{array}$ & $\begin{array}{c}0.109 \\
(3.25)^{* * *}\end{array}$ & $\begin{array}{c}0.139 \\
(4.08)^{* * *}\end{array}$ & $\begin{array}{c}0.032 \\
(1.21)\end{array}$ & $\begin{array}{c}0.169 \\
(5.61)^{* * *}\end{array}$ & $\begin{array}{c}0.018 \\
(0.60)\end{array}$ \\
\hline PE index 1 & $\begin{array}{c}0.062 \\
(1.04)\end{array}$ & $\begin{array}{l}-0.190 \\
(5.68)^{* * *}\end{array}$ & $\begin{array}{c}-0.098 \\
(1.94)^{*}\end{array}$ & $\begin{array}{c}0.063 \\
(1.10)\end{array}$ & $\begin{array}{c}-0.073 \\
(1.49)\end{array}$ & $\begin{array}{c}-0.028 \\
(0.81)\end{array}$ & $\begin{array}{l}-0.139 \\
(3.78)^{* * *}\end{array}$ & $\begin{array}{c}0.060 \\
(1.05)\end{array}$ & $\begin{array}{c}-0.043 \\
(1.26)\end{array}$ & $\begin{array}{c}-0.092 \\
(1.39)\end{array}$ & $\begin{array}{c}0.103 \\
(1.64)\end{array}$ \\
\hline common colony & $\begin{array}{c}0.167 \\
(0.85)\end{array}$ & $\begin{array}{c}-0.038 \\
(0.24)\end{array}$ & $\begin{array}{l}0.679 \\
(2.11)^{* *}\end{array}$ & $\begin{array}{c}0.160 \\
(0.58)\end{array}$ & $\begin{array}{l}-0.546 \\
(1.66)^{*}\end{array}$ & $\begin{array}{c}0.309 \\
(0.87)\end{array}$ & $\begin{array}{c}0.034 \\
(0.16)\end{array}$ & $\begin{array}{c}-0.234 \\
(1.35)\end{array}$ & $\begin{array}{c}-0.176 \\
(0.71)\end{array}$ & $\begin{array}{c}0.281 \\
(1.00)\end{array}$ & $\begin{array}{l}0.417 \\
(1.85)^{*}\end{array}$ \\
\hline common ethnic language & $\begin{array}{c}0.385 \\
(3.29)^{* * *}\end{array}$ & $\begin{array}{c}0.306 \\
(2.73)^{* * *}\end{array}$ & $\begin{array}{c}0.560 \\
(3.70)^{* * *}\end{array}$ & $\begin{array}{c}0.306 \\
(2.95)^{* * *}\end{array}$ & $\begin{array}{c}0.208 \\
(1.52)\end{array}$ & $\begin{array}{l}0.284 \\
(2.48)^{* * *}\end{array}$ & $\begin{array}{c}0.410 \\
(4.05)^{* * *}\end{array}$ & $\begin{array}{c}0.560 \\
(5.16)^{* * *}\end{array}$ & $\begin{array}{c}0.403 \\
(5.11)^{* * *}\end{array}$ & $\begin{array}{l}0.424 \\
(2.19)^{* *}\end{array}$ & $\begin{array}{c}0.390 \\
(2.58)^{* * *}\end{array}$ \\
\hline contiguous & $\begin{array}{l}0.221 \\
(1.86)^{*}\end{array}$ & $\begin{array}{c}0.529 \\
(6.49)^{* * *}\end{array}$ & $\begin{array}{c}0.429 \\
(3.39)^{* * *}\end{array}$ & $\begin{array}{c}0.799 \\
(10.44)^{* * *}\end{array}$ & $\begin{array}{c}0.544 \\
(4.36)^{* * *}\end{array}$ & $\begin{array}{c}0.902 \\
(9.84)^{* * *}\end{array}$ & $\begin{array}{c}0.575 \\
(6.12)^{* * *}\end{array}$ & $\begin{array}{c}0.644 \\
(4.50)^{* * *}\end{array}$ & $\begin{array}{c}0.763 \\
(10.08)^{* * * *}\end{array}$ & $\begin{array}{c}0.754 \\
(3.37)^{* * *}\end{array}$ & $\begin{array}{c}0.948 \\
(4.42)^{* * *}\end{array}$ \\
\hline former colony & $\begin{array}{c}0.749 \\
(4.72)^{* * *}\end{array}$ & $\begin{array}{l}0.268 \\
(1.73)^{*}\end{array}$ & $\begin{array}{c}0.120 \\
(0.70)\end{array}$ & $\begin{array}{c}0.455 \\
(3.13)^{* * *}\end{array}$ & $\begin{array}{c}-0.364 \\
(1.81)^{*}\end{array}$ & $\begin{array}{l}0.275 \\
(2.34)^{* *}\end{array}$ & $\begin{array}{l}0.293 \\
(2.33)^{* *}\end{array}$ & $\begin{array}{c}0.130 \\
(1.06)\end{array}$ & $\begin{array}{c}0.122 \\
(1.27)\end{array}$ & $\begin{array}{c}0.917 \\
(3.82)^{* * *}\end{array}$ & $\begin{array}{c}0.178 \\
(0.96)\end{array}$ \\
\hline shallow FTA (DESTA=1,2) & $\begin{array}{l}-0.921 \\
(3.34)^{* * *}\end{array}$ & $\begin{array}{c}0.576 \\
(3.61)^{* * *}\end{array}$ & $\begin{array}{c}0.348 \\
(1.44)\end{array}$ & $\begin{array}{c}0.335 \\
(2.61)^{* * *}\end{array}$ & $\begin{array}{c}-0.217 \\
{ }_{(0.60)}\end{array}$ & $\begin{array}{c}0.241 \\
(1.02)\end{array}$ & $\begin{array}{c}0.946 \\
(5.04)^{* * *}\end{array}$ & $\begin{array}{c}-0.428 \\
(1.92)^{*}\end{array}$ & $\begin{array}{c}0.887 \\
(3.82)^{* * *}\end{array}$ & $\begin{array}{c}-0.618 \\
(1.24)\end{array}$ & $\begin{array}{l}0.921 \\
(2.57)^{* *}\end{array}$ \\
\hline medium FTA (DESTA $=3,4,5)$ & $\begin{array}{c}-0.193 \\
(0.94)\end{array}$ & $\begin{array}{c}0.070 \\
(0.40)\end{array}$ & $\begin{array}{c}-0.201 \\
(0.67)\end{array}$ & $\begin{array}{c}-0.140 \\
(0.74)\end{array}$ & $\begin{array}{l}0.594 \\
(2.55)^{* *}\end{array}$ & $\begin{array}{l}-0.442 \\
(3.03)^{* * *}\end{array}$ & $\begin{array}{l}-0.415 \\
(2.70)^{* * *}\end{array}$ & $\begin{array}{c}0.088 \\
(0.49)\end{array}$ & $\begin{array}{c}-0.203 \\
(1.87)^{*}\end{array}$ & $\begin{array}{c}1.108 \\
(3.43)^{* * *}\end{array}$ & $\begin{array}{c}1.362 \\
(4.14)^{* * *}\end{array}$ \\
\hline deep FTA $($ DESTA $=6,7)$ & $\begin{array}{c}1.493 \\
(4.00)^{* * *}\end{array}$ & $\begin{array}{c}1.163 \\
(5.54)^{* * *}\end{array}$ & $\begin{array}{c}1.266 \\
(4.04)^{* * *}\end{array}$ & $\begin{array}{c}0.811 \\
(3.82)^{* * *}\end{array}$ & $\begin{array}{c}2.083 \\
(8.11)^{* * *}\end{array}$ & $\begin{array}{c}1.028 \\
(3.52)^{* * *}\end{array}$ & $\begin{array}{c}1.504 \\
(5.06)^{* * *}\end{array}$ & $\begin{array}{c}2.383 \\
(8.91)^{* * *}\end{array}$ & $\begin{array}{c}1.252 \\
(7.21)^{* * *}\end{array}$ & $\begin{array}{c}1.569 \\
(4.20)^{* * *}\end{array}$ & $\begin{array}{c}4.088 \\
(10.09)^{* * *}\end{array}$ \\
\hline European Union & $\begin{array}{c}0.527 \\
(2.93)^{* * *}\end{array}$ & $\begin{array}{c}0.632 \\
(5.09)^{* * *}\end{array}$ & $\begin{array}{c}0.710 \\
(3.75)^{* * *}\end{array}$ & $\begin{array}{c}0.175 \\
(1.41)\end{array}$ & $\begin{array}{c}1.008 \\
(7.02)^{* * *}\end{array}$ & $\begin{array}{c}0.343 \\
(3.05)^{* * *}\end{array}$ & $\begin{array}{c}-0.035 \\
(0.30)\end{array}$ & $\begin{array}{c}1.017 \\
(6.74)^{* * *}\end{array}$ & $\begin{array}{c}0.449 \\
(3.91)^{* * *}\end{array}$ & $\begin{array}{l}0.622 \\
(1.97)^{* *}\end{array}$ & $\begin{array}{c}-1.023 \\
(1.60)\end{array}$ \\
\hline $\begin{array}{l}N \\
\text { pseudo } R^{2} \\
\text { V: distance share of variance }\end{array}$ & $\begin{array}{l}11,863 \\
0.9874 \\
0.1886\end{array}$ & $\begin{array}{l}11,863 \\
0.9766 \\
0.0401\end{array}$ & $\begin{array}{l}11,863 \\
0.9619 \\
0.0435\end{array}$ & $\begin{array}{l}11,863 \\
0.9789 \\
0.0617\end{array}$ & $\begin{array}{l}11,863 \\
0.9763 \\
0.0583\end{array}$ & $\begin{array}{l}11,863 \\
0.9849 \\
0.0757\end{array}$ & $\begin{array}{l}11,863 \\
0.9760 \\
0.0270\end{array}$ & $\begin{array}{l}11,863 \\
0.9854 \\
0.1443\end{array}$ & $\begin{array}{l}11,863 \\
0.9879 \\
0.0948\end{array}$ & $\begin{array}{l}11,863 \\
0.9369 \\
0.1095\end{array}$ & $\begin{array}{c}9,955 \\
0.8530 \\
0.0404\end{array}$ \\
\hline
\end{tabular}

Notes: PPML estimates, all including source and destination fixed effects (not shown). PE index

1 and PE index 2 are composite variables of similarity in political economy indicators as discussed in text. The variables shallow FTA, medium FTA and deep FTA have been instrumented for. Standard errors in parenthesis. Significance levels: ${ }^{* * *} p<0.01,{ }^{* *} p<0.05,{ }^{*} p<0.1$. Sector codes: B_T beverages \& tobacco; CRP chemicals, rubber, plastics; ELE electrical machinery; MTL metals; MVH motor vehicles; OGD other goods; OMC other machinery; PRA primary agriculture; PRE primary energy; PRF processed foods; P_C petrochemicals. The statistic V, for predicted log-linear trade values, is $b_{2}^{2} V A R(\ln ($ distance $)) / V A R \ln ($ trade $)$.

observable variables and importer (exporter) specific trade costs. The technology parameters are obtained by writing the technology parameters $z_{i s}$ as a function of the exporter (with importer specific trade costs) or importer fixed effects (with exporter specific trade costs) and the price of input bundles $c_{i s}$ (Eaton and Kortum, 2002 Shikher, 2012, Levchenko and Zhang, 2015). With data on $c_{i s}$, the $z_{i s}$ can then easily be obtained.

We follow a different route, inspired by recent work by Egger and Nigai (2014) and Egger and Nigai (2015) and the CGE literature. Egger and Nigai (2014) argue that exporter and importer fixed effects are picking up part of the unobservable trade costs and only importer or exporter specific unobserved trade costs is not enough to account for that. Neglecting the unobservable trade costs results in a relatively large difference between actual and predicted trade values. In calibrating an Eaton 
and Kortum economy, Egger and Nigai (2015) propose to calculate trade costs and technology parameters from actual import shares, imposing that there is a perfect fit between actual and predicted normalised trade shares and that income is equal to exports to all destination countries ${ }^{22}$ We follow this approach and thus solve $t_{i j s}$ and $T_{i s}$ from the following set of equations:

$$
\begin{aligned}
\frac{\omega_{i j s}}{\omega_{j j s}} & =\frac{\left(\frac{c_{i s}}{z_{i s}} t_{i j s}\right)^{-\theta_{s}}}{\left(\frac{c_{j s}}{z_{j s}} t_{j j s}\right)^{-\theta_{s}}} \\
\operatorname{prod}_{i s} & =\sum_{j=1}^{J} \frac{\left(\frac{c_{i s}}{z_{i s}} t_{i j s}\right)^{-\theta_{s}}}{\sum_{k=1}^{J}\left(\frac{c_{k s}}{z_{k s}} t_{k j s}\right)^{-\theta_{s}}} \mathrm{dem}_{j s}
\end{aligned}
$$

where $\omega_{i j s}$ is the market share of imports from country $i$ in total demand in country $j$ and $\operatorname{prod}_{i s}$ and $d_{e} m_{j s}$ are respectively the value of production in country $i$ and demand in country $j$. In comparison with a calibration based on observable trade costs only, the perfect fit is achieved, because total trade costs consist of a mix of observable and unobservable trade costs. Since our numerical model is written in relative changes the exact value of trade costs $t_{i j s}$ and technology $T_{i s}$ following from equations (8)-(9) is irrelevant for model simulations. It is only required that the predicted import shares are equal to the actual market shares in the baseline.

\subsection{Trade cost reductions}

The reduction in distance as a result of the NSR has an impact on two types of trade costs, international transport services and iceberg trade costs. The percentage reduction in international transport services costs, $\Delta \ln i s_{i j s}$, (the "atall" in the GTAP code) is calculated as the reduction in distance times the elasticity of international transport services costs with respect to distance, $\eta_{\text {its,dist }}$ :

$$
\Delta \ln i t s_{i j s}=-\eta_{i t s, d i s t}\left(\frac{\text { NSRdistance }_{i j}}{\text { distance }_{i j}}-1\right)
$$

To calculate $\eta_{i t s, d i s t}$ international transport services are regressed on distance, while controlling for port infrastructure and including industry fixed effects. This equation is estimated restricting the sample to European and East Asian countries for three reasons. First, the quality of the transport service data is poor for many other countries (in particular the African countries). Second, the NSR is about a reduction in shipping distances between Europe and East Asia. And third, the empirical literature on the determinants of shipping costs shows that the effect of is nonlinear (OECD, 2008). Table 3 shows that the estimated elasticity $\eta_{i t s, d i s t}$ is equal to 0.78923

\footnotetext{
${ }^{22}$ This approach is similar to the approach in the CGE literature with the Armington shifters set such that there is a perfect fit between actual an fitted trade flows.

${ }^{23} \mathrm{~A}$ series of papers find that the elasticity of shipping costs to distance is around 0.2 (Radelet and Sachs, 1998, Fink et al., 2000, Limão and Venables, 2001, Micco and Pérez, 2002, Clark et al.
} 
Table 3: Regression of shipping costs and shipping distances for Europe-Asia trade

\begin{tabular}{lc}
\hline ports & -0.047 \\
& $(4.12)^{* * *}$ \\
$\ln$ (distance) & 0.789 \\
& $(5.56)^{* * *}$ \\
Cons & -4.216 \\
& $(3.02)^{* * *}$ \\
$R^{2}$ & 0.64 \\
$N$ & 2,448
\end{tabular}

Notes: PQML estimates of shipping rate (in percent). Includes industry dummies. Ports is a WEF/World Bank index of port quality.

In Table 4 we present a summary of the transport cost reductions. These are sector-specific and vary by trading country pairs. Moreover, the transport cost changes are not symmetric -i.e. the trade costs from China to Germany are different than from Germany to China.

A fall in distance does not only affect international transport service costs but also other barriers to bilateral trade such as information costs, business networks, cultural barriers, time, coordination, and other non-shipping service costs (cf. Hummels and Schaur, 2013). In our framework, these additional trade barriers are captured by the iceberg costs, so the NSR will also reduce iceberg trade costs. The percentage reduction in iceberg trade $\operatorname{costs} \Delta \ln \tau_{i j s}$ (the "ams" in the GTAP code) is calculated as the reduction in distance as a result of the NSR times the elasticity of trade costs with respect to distance. The elasticity of trade costs with respect to distance is calculated from the distance and tariff elasticities in Table 2. This gives the following expression for $\Delta \ln \tau_{i j s}$ :

$$
\Delta \ln \tau_{i j s}=\frac{\beta_{s, \text { distance }}}{\theta_{s}+1}\left(\frac{\text { NSRdistance }_{i j}}{\text { distance }_{i j}}-1\right)
$$

Since international transport services are also included as a regressor in the gravity equation, the effect of distance on trade costs and thus on trade flows through international transport services is accounted for separately. Therefore, we can attribute the entire effect of distance from the gravity equation to a reduction in iceberg trade costs. Our estimates of $\Delta \ln \tau_{i j s}$ are summarised in Table 5 below. Note that these iceberg trade costs are also country-pair and sector-specific and are also not symmetric.

2004). However, OECD (2008) use the most comprehensive shipping costs dataset to date and find that the effect is non-linear, presents large variations between goods, and is asymmetric in costs between the same routes. Therefore, our relatively high elasticity can be reconciled with the existing literature, because distance seems to matter more for shipping costs between East Asia and Europe. 
Table 4: International transport cost reductions for 11 non-services sectors for selected countries.

\begin{tabular}{|c|c|c|c|c|c|c|c|c|c|}
\hline \multirow[b]{2}{*}{ From: } & \multirow[b]{2}{*}{ To: } & \multicolumn{3}{|c|}{ cost reductions } & \multirow[b]{2}{*}{ From: } & \multirow[b]{2}{*}{ To: } & \multicolumn{3}{|c|}{ cost reductions } \\
\hline & & average & $\max$ & $\min$ & & & average & $\max$ & $\min$ \\
\hline DEU & CHN & 21.73 & 22.15 & 17.48 & $\mathrm{CHN}$ & DEU & 20.49 & 20.89 & 16.48 \\
\hline DEU & JPN & 33.07 & 33.71 & 26.60 & $\mathrm{CHN}$ & FRA & 4.69 & 4.78 & 3.77 \\
\hline \multirow[t]{2}{*}{ DEU } & KOR & 26.62 & 27.14 & 21.42 & $\mathrm{CHN}$ & GBR & 21.19 & 21.61 & 17.05 \\
\hline & & & & & $\mathrm{CHN}$ & NLD & 20.96 & 21.37 & 16.86 \\
\hline FRA & $\mathrm{CHN}$ & 6.37 & 6.50 & 5.13 & & & & & \\
\hline FRA & JPN & 21.00 & 21.41 & 16.89 & JPN & DEU & 32.95 & 33.59 & 26.50 \\
\hline \multirow[t]{2}{*}{ FRA } & KOR & 12.77 & 13.02 & 10.27 & JPN & FRA & 20.96 & 21.37 & 16.86 \\
\hline & & & & & JPN & GBR & 34.00 & 34.67 & 27.35 \\
\hline GBR & $\mathrm{CHN}$ & 22.41 & 22.84 & 18.02 & JPN & NLD & 33.65 & 34.31 & 27.07 \\
\hline GBR & JPN & 34.13 & 34.80 & 27.45 & & & & & \\
\hline \multirow[t]{2}{*}{ GBR } & KOR & 27.47 & 28.01 & 22.10 & KOR & DEU & 25.40 & 25.90 & 20.43 \\
\hline & & & & & KOR & FRA & 11.13 & 11.35 & 8.95 \\
\hline NLD & $\mathrm{CHN}$ & 22.16 & 22.59 & 17.83 & KOR & GBR & 26.28 & 26.79 & 21.14 \\
\hline NLD & JPN & 33.77 & 34.43 & 27.17 & KOR & NLD & 26.00 & 26.51 & 20.91 \\
\hline NLD & KOR & 27.18 & 27.71 & 21.86 & & & & & \\
\hline
\end{tabular}

Notes: Average is the mean iceberg cost reductions between all 11 manufacturing sectors, while max and min are the maximum and minimum cost reductions, respectively. Codes: DEU

(Germany), FRA (France), GBR (United Kingdom), NLD (Netherlands), CHN (China), JPN

(Japan) and KOR (South Korea). Source: Own estimations.

\subsection{Additional parameters}

The three remaining sets of parameters come from the GTAP model ${ }^{24}$ First, the largest set of parameters are those related to the CDE utility function. To start, the substitution parameters $\gamma_{j s}$ are calculated from the own-price elasticities of substitution. The expansion parameters $\eta_{j s}$ can then be calculated from income elasticities and the $\gamma_{j s}$. The own-price elasticities are based on spending shares and income elasticities with the income elasticities varying by region and taken from different sources 25 Second, the substitution elasticities between factor inputs in each of the sectors are based on a review of the empirical literature in the SALTER project (Zeitsch et al. 1991). The values range between 0.25 for agricultural goods and 1.68 for the transport sector. Third, the parameter governing investment reallocation between countries is set at 10, implying that investments are reallocated across countries at a modest rate.

\footnotetext{
${ }^{24}$ The main characteristics and references to the standard GTAP model can be found at: www.gtap.agecon.purdue.edu/models/current.asp. See also Hertel (2013) and Rutherford and Palt$\operatorname{sev}(2000)$ for a more detailed discussion.

${ }^{25}$ See Huff et al. (1997) for further discussion of the sources of the income elasticities and the calibration procedure .
} 
Table 5: Iceberg trade cost reductions for 11 non-services sectors for selected countries.

\begin{tabular}{|c|c|c|c|c|c|c|c|c|c|}
\hline \multirow[b]{2}{*}{ From: } & \multirow[b]{2}{*}{ To: } & \multicolumn{3}{|c|}{ iceberg cost reductions } & \multirow[b]{2}{*}{ From: } & \multirow[b]{2}{*}{ To: } & \multicolumn{3}{|c|}{ iceberg cost reductions } \\
\hline & & average & $\max$ & $\min$ & & & average & $\max$ & $\min$ \\
\hline DEU & $\mathrm{CHN}$ & 2.85 & 4.46 & 0.62 & $\mathrm{CHN}$ & DEU & 2.68 & 4.19 & 0.58 \\
\hline DEU & JPN & 4.48 & 7.03 & 1.01 & $\mathrm{CHN}$ & FRA & 0.59 & 0.92 & 0.12 \\
\hline \multirow[t]{2}{*}{ DEU } & KOR & 3.54 & 5.55 & 0.78 & $\mathrm{CHN}$ & GBR & 2.77 & 4.35 & 0.60 \\
\hline & & & & & $\mathrm{CHN}$ & NLD & 2.74 & 4.30 & 0.60 \\
\hline FRA & $\mathrm{CHN}$ & 0.80 & 1.26 & 0.17 & & & & & \\
\hline FRA & JPN & 2.75 & 4.31 & 0.60 & JPN & $\mathrm{DEU}$ & 4.46 & 7.00 & 1.01 \\
\hline \multirow[t]{2}{*}{ FRA } & KOR & 1.64 & 2.56 & 0.35 & JPN & FRA & 2.74 & 4.30 & 0.60 \\
\hline & & & & & JPN & GBR & 4.62 & 7.25 & 1.05 \\
\hline GBR & $\mathrm{CHN}$ & 2.94 & 4.61 & 0.64 & JPN & NLD & 4.57 & 7.16 & 1.03 \\
\hline GBR & JPN & 4.64 & 7.28 & 1.05 & & & & & \\
\hline \multirow[t]{2}{*}{ GBR } & KOR & 3.66 & 5.74 & 0.81 & KOR & DEU & 3.36 & 5.27 & 0.74 \\
\hline & & & & & KOR & FRA & 1.42 & 2.22 & 0.30 \\
\hline NLD & $\mathrm{CHN}$ & 2.91 & 4.56 & 0.63 & KOR & GBR & 3.49 & 5.47 & 0.77 \\
\hline NLD & $\mathrm{JPN}$ & 4.59 & 7.19 & 1.04 & KOR & NLD & 3.45 & 5.41 & 0.76 \\
\hline NLD & KOR & 3.62 & 5.67 & 0.80 & & & & & \\
\hline
\end{tabular}

Notes: Average is the mean iceberg cost reductions between all 11 manufacturing sectors, while max and min are the maximum and minimum cost reductions, respectively. Codes: DEU (Germany), FRA (France), GBR (United Kingdom), NLD (Netherlands), CHN (China), JPN (Japan) and KOR (South Korea). Source: Own estimations.

\subsection{Data}

To assess the global general equilibrium effects of the commercial use of the Northern Sea Route, we work with the GTAP9 database with base-year 2011, projected along the medium or SSP2 (Shared Socioeconomic Pathway) from the most recent SSPs and related Integrated Assessment scenarios (IIASA, 2012, O'Neill et al., 2012), 26 In the paper, we focus on the year 2030 from this baseline. Our model allows us to analyse both the trade and macroeconomic implications associated with the NSR, as well as changes in $\mathrm{CO} 2$ emissions from production and international transport. ${ }^{27}$ We aggregate the 57 GTAP sectors into 16 sectors, and the 129 regions into 110 countries (see Table 8 and Table 9 in the Appendix) 28

\footnotetext{
${ }^{26}$ These are standard macroeconomic projections used in the related literature. These projections provide the baseline scenario against which our simulations are compared. Hence, the use of a particular baseline scenario will not change qualitatively our main results.

${ }^{27}$ GTAP is the standard basic data used in most CGE models. See Narayanan et al. (2012) for documentation on the GTAP database, and Hertel (2013) on the full database project.

${ }^{28}$ The model is implemented in GEMPACK under OSX and the model code is available upon request, as well as an executable version of the model.
} 


\section{Counterfactual analysis of reductions in trade costs through the NSR}

To assess the global general equilibrium effects of the commercial use of the Northern Sea Route, working from the 2030 projections, our main simulation results are the differences between the baseline values in 2030 (i.e. the business-as-usual scenario with no NSR shipping) compared with the counterfactual scenario where we allow bilateral trade to move through the NSR. In this counterfactual scenario, we include both the transport and trade cost reductions as discussed above into our CGE model to assess the impact on bilateral trade flows, sectoral output, and other macroeconomic variables ${ }^{29}$ We also look into the social costs of these trade changes in terms of overall welfare, and employment/wage changes. We also analyse the changes that shorter shipping routes have on transport related pollution levels, which account for both shorter distances but also on potentially larger trade volumes.

\subsection{Trade effects}

Once we run the counterfactual simulation, we obtain global and bilateral trade changes. These changes in trade represent the difference by 2030 -when we assume that the NSR will be fully operational- between the current use of the SSR and the NSR. First, we find that using the NSR will reduce international shipping (volume by distance) by $0.44 \%$, but global trade volumes increase by $0.21 \%$. Although these global trade volume changes are not radically high, they are completely concentrated in trade changes between Northeast Asia (i.e. China, Japan and South Korea) and Northern Europe. For instance, we estimate that the share of World trade that is re-routed through the NSR will be of $5.5 \%$. Of the total Chinese trade in 2030, we project that $14.9 \%$ will use the NSR.

Table 6 shows the bilateral trade changes in trade values for goods and services for the main four Northeast Asian exporters. We can observe the significant changes in export and import values of the three main Asia countries that benefit from the NSR: China, Japan, and South Korea.

First, we observe how Northwestern countries significantly increase their exports to China, Japan and South Korea. This group is compromised of Austria, Belgium, Denmark, Finland, France, Germany, Ireland, the Netherlands, Sweden, and the United Kingdom. Trade with France, Spain and Portugal is also increasing but less than in the previous group. On the other hand, trade with Northeast Asia is barely changing or even decreasing for the Mediterranean European countries (i.e. Italy and Greece). An interesting case is Eastern Europe, where some countries closer to the North increase their exports to Northeastern Asia (e.g. Czech Republic, Estonia, Latvia, Lithuania, Poland and Slovakia), while others have no significant export increases (Bulgaria, Croatia, Hungary, Romania and Slovenia). In Table 10

\footnotetext{
${ }^{29}$ As explained in Section 5 this is done through a mix of both technical efficiency in shipping and iceberg trade costs, where in total these are equivalent to estimated reductions in total trade costs.
} 
Table 6: Northeast Asia, changes in total trade values for selected countries, percentage changes

\begin{tabular}{|c|c|c|c|c|c|c|}
\hline & \multicolumn{2}{|c|}{ China } & \multicolumn{2}{|c|}{ Japan } & \multicolumn{2}{|c|}{ South Korea } \\
\hline & exports & imports & exports & imports & exports & imports \\
\hline Austria & 12.64 & 10.36 & 10.97 & 17.10 & 8.95 & 11.78 \\
\hline Belgium & 12.34 & 11.28 & 15.82 & 10.82 & 14.69 & 11.86 \\
\hline Bulgaria & -1.71 & 0.69 & -0.81 & 0.41 & -1.25 & 0.16 \\
\hline Croatia & -1.29 & 0.57 & -1.18 & -0.01 & -0.80 & 0.20 \\
\hline Czech Republic & 8.17 & 15.44 & 15.15 & 18.60 & 10.49 & 18.51 \\
\hline Denmark & 11.43 & 9.39 & 2.64 & 11.31 & 5.76 & 9.19 \\
\hline Estonia & 10.75 & 12.03 & 9.31 & 14.55 & 11.73 & 6.19 \\
\hline Finland & 10.98 & 6.91 & 11.77 & 16.03 & 10.44 & 12.49 \\
\hline France & 1.51 & 3.41 & 9.17 & 7.81 & 4.18 & 6.46 \\
\hline Germany & 10.53 & 10.37 & 13.88 & 11.54 & 7.07 & 12.58 \\
\hline Greece & -0.99 & 0.49 & -0.45 & 0.27 & -0.72 & 0.16 \\
\hline Hungary & -2.08 & 0.50 & -1.44 & 1.09 & -1.38 & 0.89 \\
\hline Ireland & 6.56 & 6.99 & 3.64 & 11.78 & 18.68 & 8.90 \\
\hline Italy & -1.42 & 0.97 & -1.06 & 0.17 & -0.87 & 0.30 \\
\hline Latvia & 11.37 & 14.31 & 5.59 & 10.34 & 11.26 & 11.67 \\
\hline Lithuania & 11.03 & 10.07 & 9.18 & 11.36 & 12.91 & 7.00 \\
\hline Netherlands & 10.62 & 9.40 & 14.96 & 12.98 & 13.18 & 12.79 \\
\hline Poland & 11.02 & 13.51 & 13.64 & 16.71 & 9.87 & 14.71 \\
\hline Portugal & -0.60 & 0.89 & 3.16 & 3.70 & 3.76 & 1.36 \\
\hline Romania & -1.79 & 0.77 & -1.25 & 0.26 & -1.25 & 0.25 \\
\hline Slovakia & 7.68 & 6.06 & 14.37 & 9.15 & 9.66 & 14.64 \\
\hline Slovenia & -1.59 & 1.18 & -1.05 & 0.50 & -0.82 & 0.86 \\
\hline Spain & -0.64 & 0.99 & 5.50 & 4.61 & 1.97 & 2.12 \\
\hline Sweden & 12.70 & 10.53 & 13.37 & 17.97 & 9.95 & 12.02 \\
\hline United Kingdom & 12.33 & 8.23 & 12.30 & 7.77 & 7.95 & 8.98 \\
\hline EU28 & 6.72 & 7.48 & 10.23 & 9.01 & 6.49 & 8.62 \\
\hline Norway & 12.63 & 12.93 & 12.91 & 13.20 & 5.19 & 10.43 \\
\hline Turkey & -1.31 & 0.40 & -1.03 & 0.32 & -0.81 & 0.14 \\
\hline United States & -0.72 & 0.46 & -0.58 & 0.14 & -0.30 & 0.06 \\
\hline
\end{tabular}

Source: Own estimations using the GTAP database.

in the Appendix we show the corresponding data for merchandise trade in volumes, which shows a similar pattern to the one described above.

This remarkable increase in bilateral trade between two relatively large economic zones is translated into a significant diversion of trade -i.e. the bilateral trade flows between Northeast Asia and Northwestern Europe significantly increase at the expense of less trade with other regions. The main diversion effect is that there is a sizeable reduction in intra-European trade, with less trade between Northwestern Europe with South and Eastern Europe. Figure 3 shows these trade diversion patterns.

The precise figures for the countries in Figure 3 and additional countries is presented in Tables 11 in the Appendix, were we can clearly observe this trade diversion pattern. First, German trade increases by around $11 \%$ to Northeast Asia (i.e. 
Figure 3: Trade flows after opening the NSR: percentage changes in exports by selected countries
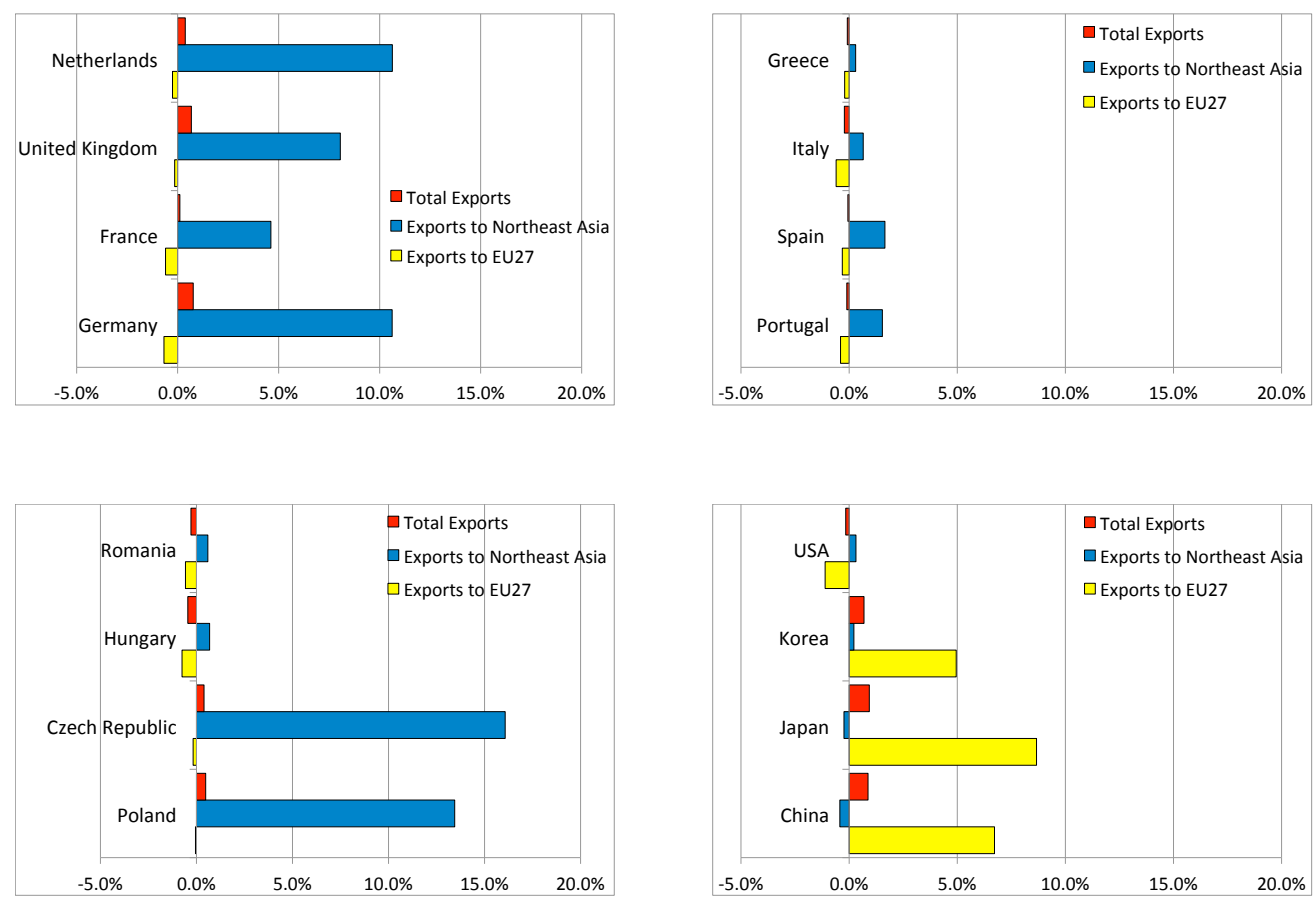

Source: Own estimations using the GTAP database.

Japan, South Korea and China), while trade with other European countries slightly decreasing (by around half percentage point), with Eastern European countries experiencing the biggest decrease of one percentage points. This pattern of changes in German exports is also replicated by the other Northwestern European countries (e.g. Austria, Belgium, Ireland, the Netherlands, Sweden and the United Kingdom). This is also the case for some Eastern European countries that are closer to the Baltic sea (i.e. Poland and the Czech Republic). France, Spain and Portugal also increase their trade with Northeast Asia but at a much lower level rate between $3 \%$ and $1 \%$, which does not compensate for the reduction of intra-European trade and thus, overall trade barely changes for these countries. On the other hand, the other Mediterranean countries (Italy, Greece) and Eastern European countries (Hungary, Romania) experience a decrease in trade with both Asia and Europe that is reflected in an overall reduction of trade. Finally, the Northeast Asian countries show that exports increase significantly to Northwestern Europe while experiencing a slight decrease for the rest of the World (RoW).

This pattern of trade diversion can also be seen when we look at exports at the sectoral level. For instance, Tables 12 and 13 in the Appendix show the sectoral changes in exports to China and Germany. We observe that sectoral exports are 
evenly spread among all manufacturing sectors with few exceptions (mainly the service sectors). Looking at the trade flows to Europe, in Table 13 we show the percentage changes in export sales to Germany -which has a very similar pattern from exports to other Northwestern European countries. Here we find that China, Japan and South Korea significantly increase their exports to Germany in almost all sectors but services, while all other European countries decrease their exports to Germany.

Overall, even when trade diversion is significant, aggregate exports do not change significantly. In Figure 4 we show the changes in aggregate export volumes by country. We observe that Northwestern European countries increase there export volumes, since the increase of exports to Asia compensates for less intra-European trade. However, Southern and Eastern European countries have a decrease in exports due to the reduction of exports to other Europe countries, which is not fully compensated by exports to third regions.

Figure 4: Changes in export values for selected countries, percentage changes

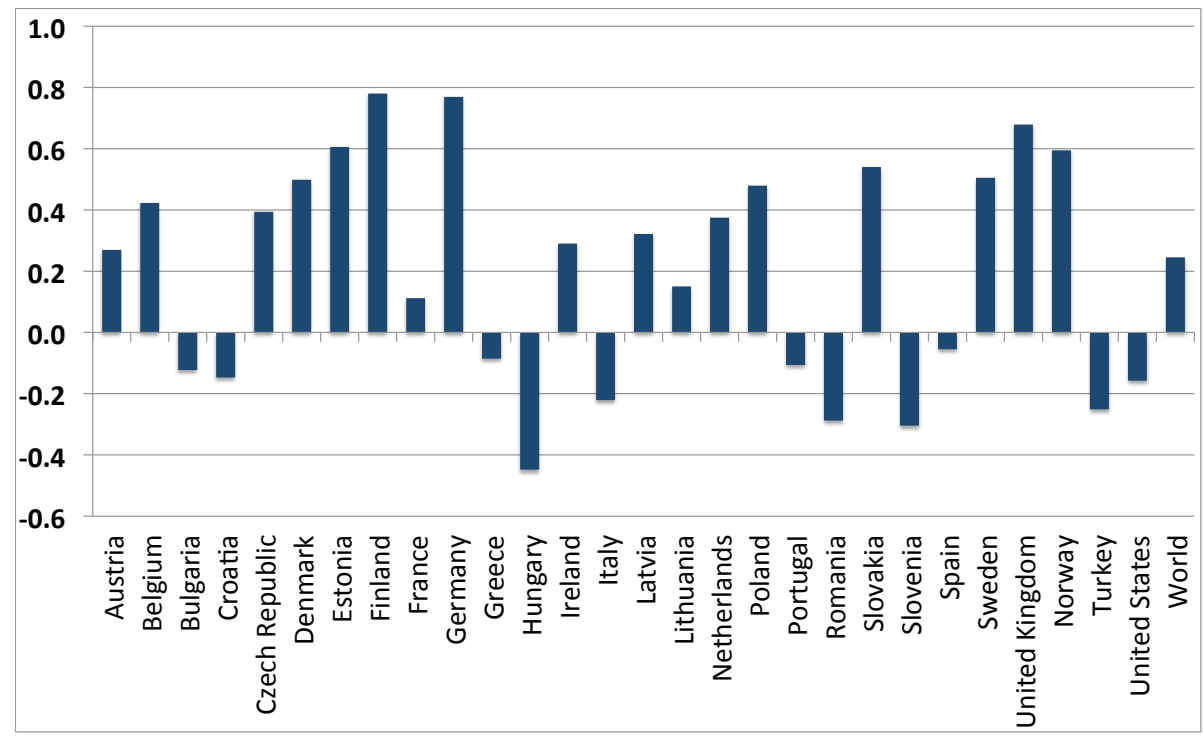

Source: Own estimations using the GTAP database.

\subsection{Macroeconomic outcomes}

The changes in trade flows are translated into macroeconomic impacts as well. First, GDP and welfare (measured as per capita utility percentage changes) are estimated to increase modestly in the countries that benefit directly from the NSR (see Figure 5) 30 Northeast Asia, Northwestern Europe (and also Poland and the Czech Republic) experience the biggest gains. On the contrary, most South and Eastern

\footnotetext{
${ }^{30}$ See also Table 14 in the Appendix for the GDP and real income changes for all countries. There we also present two measure of welfare changes: per capita utility and equivalent variation in US\$
} 
European countries experience GDP decreases. This last effect is caused by the disruption in intra-EU trade and regional production value chains caused by the opening of the NSR. The associated trade diversion pattern is therefore negatively affecting the South and Eastern EU members states. To put these effects in perspective, these GDP impacts -in the range of less than half a percentage point of GDP - are comparable to estimated effects from an EU-US free trade agreement, or the Doha and Uruguay Rounds of multilateral trade negotiations. 31

Figure 5: GDP and welfare changes associated with the opening of the NSR for selected countries, percentage changes

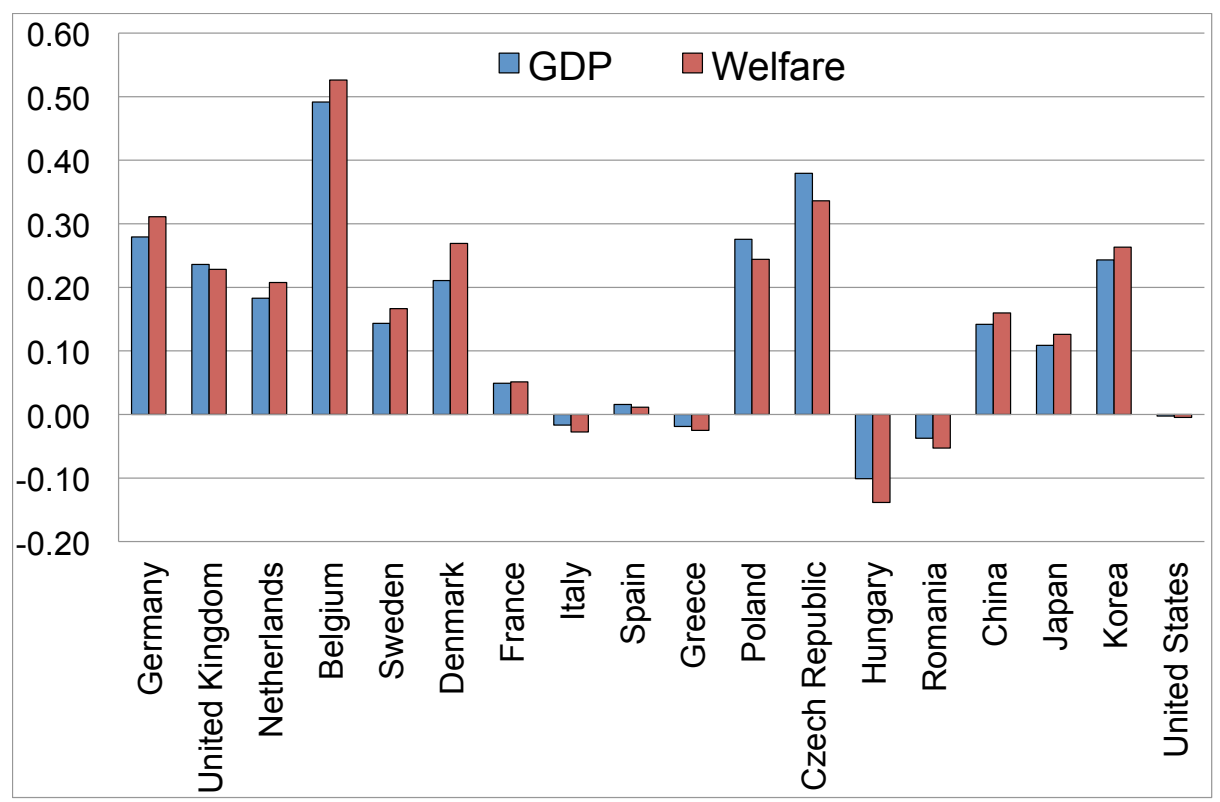

Note: Welfare is measured as per capita utility. Source: Own estimations using the GTAP database.

We can observe from Figure 6 that there is a direct relationship between these real income changes and the country-specific changes in exports (and overall trade volumes). In general, countries that increase their exports are those that also benefit from the opening of the NSR. The linkage between trade and welfare gains, therefore, is provided by the use (or not) of the new trade possibilities associated with the NSR. In particular, the positive welfare and GDP effects are driven by the reduction in the transportation and iceberg costs associated with the commercial use of the NSR. The countries that benefit from these trade costs reductions are those that will use intensively the NSR, and by extension, are the same countries that will also increase their trade volumes. On the other hand, countries that do not use the NSR will

million. Both measures of welfare experience changes that follow roughly the same pattern as GDP and real income changes; while the last welfare measure shows changes in US $\$$ that are directly related to country size.

${ }^{31}$ See for example Francois (2000), Francois et al. (2005), and Francois et al. (2013)). 
not benefit from the trade costs reductions and will, in addition, experience trade diversion (increased competition from other countries), which is associated with lower trade, but also with lower welfare and GDP. However, given the relatively small aggregate trade changes, sectoral output follows a similar pattern. We find that much of the sectoral output in most EU countries does not change significantly. ${ }^{32}$

Figure 6: Total export values and real income, percentage changes

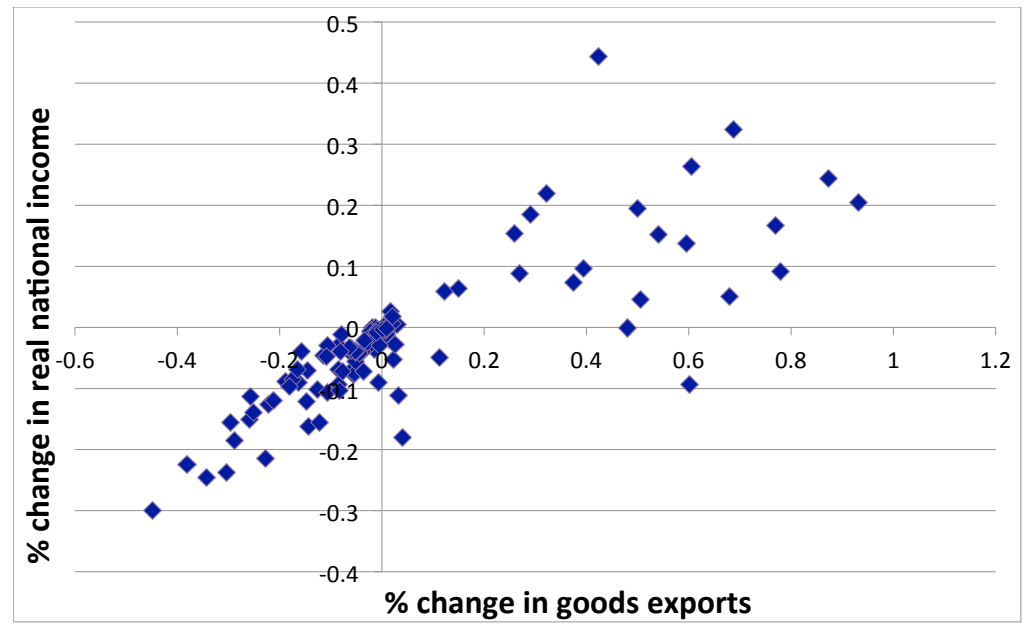

Source: Own estimations using the GTAP database.

\subsection{Labour market effects}

To analyse changes in the labour market we use two different CGE model closures. In the first -which is our benchmark model used to estimate the information presented so far- we assume a flexible labour supply, sticky wages and the labour market is cleared by changes in overall employment levels. ${ }^{33}$ In the second closure, we assume the labour supply is fixed and the labour market is cleared solely by changes in wages. In general, the changes in wages and employment are closely linked to changes in GDP, which in turn are related to the possibility to benefit from the use of the NSR as explained above.

In Table 15 in the Appendix, we present the changes in real wages and employment for both model closures. First, we observe that changes in real wages have a similar pattern to changes in real income. Countries that have declines in real wages are also expected to experience declines in real incomes. The sign and magnitude of the changes are similar between both model closures. Moreover, this pattern applies to both unskilled and skilled workers, which reflects that there are only minor changes in the relative demand of each skill level ${ }^{34}$

\footnotetext{
${ }^{32}$ The specific sectoral results are available upon request.

${ }^{33}$ We use a wage curve with an elasticity of 0.2 .

${ }^{34}$ This is also expected given the relatively small changes in sectoral output. The demand for skills varies by economic sectors, but if the output shares of these sectors do not change significantly,
} 
From Table 15 we also observe that aggregate employment changes by country are negligible. For the flexible labour supply closure, changes are usually below a tenth of a percentage point -i.e. the changes in real wages are not enough to affect overall labour supply. On the other hand, in the fixed labour supply closure overall employment does not change by construction, since wages adjust to maintain full employment.

However, when we look at the sectoral level, the changes in employment are more relevant. For instance, to summarise the sectoral changes in employment we construct a labour displacement indicator, which is calculated as the weighted standard deviation of the changes in sectoral employment. This is a standardised measure of the percentage change in employment by country. Although it varies much between countries, in Table 16 in the Appendix, we observe that on average around $0.5 \%$ or less of the total labour force is displaced to another sector. Furthermore, in Table 16 we also present the sectoral changes for low skill workers in three selected sectors. Here we observe that the sectoral displacement is also relatively modest (i.e. less than one percentage points).

Therefore, we do not expect andy medium nor large scale labour adjustment shocks, since the changes in sectoral output and employment will be very modest and will occur gradually according to the speed at which the NSR substitutes for the SSR.

\subsection{Changes in $\mathrm{CO} 2$ emissions}

Regarding CO2 emissions, we use the supplementary emissions data from the GTAP database. ${ }^{35}$ CO2 emissions are directly linked in the model to sectoral production and consumption. There are different emission level by sector and increasing (decreasing) the production/consumption of a particular good will increase (decrease) the emissions from that sector. Overall emissions are then defined by the consolidated changes in both sectoral production and consumption. For instance, if more polluting sectors increase production relative to less polluting sectors, then emissions will decrease. This approach assumes that the overall technological links between production, consumption and emissions remain constant, as well as the sector-specific links 36

At first it is expected that the shorter shipping distances associated with the NSR will reduce fuel costs and emissions from the water transport sector. However, the

then this is reflected in small changes in relative demand for skills and the skill premium -i.e. the difference between skilled and unskilled wages.

${ }^{35}$ The GTAP database regularly incorporates CO2 emissions data from the International Energy Agency (IEA), following UN IPCC guidelines, allocated based on GTAP energy volume data. This involves the Tier 1 method of IPCC Guidelines. See McDougall and Golub (2007) and Lee (2008) for further discussion. The integration of global input-output data with greenhouse gas is an ongoing initiative, supported in part by the EPA and including the MIT Joint Program on the Science and Policy of Global Change. Further information is available here: https://www.gtap.agecon.purdue.edu/models/energy/default.asp.

${ }^{36}$ Projecting future paths of emission technological changes by country and sector pairs is beyond the scope of this paper, so we retain this approximation. 
increase in trade volumes also means that when the shipping distance is reduced, the shipping services are increased due to the jump in trade volumes between Northern Europe and Northeastern Asia. Therefore, both effects almost offset each other, but we estimate that there is nonetheless a slight increase in global emissions of 14.2 million MT CO2 (see Table 17 in the Appendix). This increase is comparable to the annual emissions for a small countries (e.g. Latvia and Lithuania) ${ }^{37}$

Note that in these simulations we assume that the implicit emission levels by sector and country remain constant. This also means that changes in emission levels are not counteracted by policy efforts (i.e. carbon taxes, emission permits) nor by technological changes that can affect the effective emission levels by country and sector.

\section{Summary}

The commercial use of the Northern Sea Route -if ultimately made possible by further melting of the Arctic icecap- will represent a major development for the international shipping industry. The NSR represents a reduction of about one third of the average shipping distance and days of transportation with respect to the currently used Southern Sea Route. Roughly $8 \%$ of World trade is transported through the Suez Canal and we estimate that two-thirds of this volume will be re-routed over the shorter Arctic route.

These shorter shipping distances are associated with substantial reductions in the transportation and trade costs between two major economic regions: Northeast Asia and Northwestern Europe. We estimate that these overall trade costs reductions will increase the trade flows between both regions in average by around $10 \%$, depending on the specific countries involved. This will transform the NSR into one of the busiest global trading routes, which in turn implies heightened economic and geopolitical interests linked to the Arctic and tremendous economic pressure on the countries currently servicing the older SSR (e.g. Egypt and Singapore). In addition, the NSR will also imply a large volume of trade diversion, that will have a negative economic impact on South and East Europe. We also find that there will be -for specific countries and sectors- some significant labour displacement between sectors.

Finally, we estimate that the NSR will slightly increase CO2 emissions. Although the much shorter shipping distances will reduce the emissions associated with water transportation, these gains are offset by a combination of higher trade volumes and a shift to emission-intensive production in Northeast Asia.

\footnotetext{
${ }^{37}$ It is important to note that these particular $\mathrm{CO} 2$ results are relative to the baseline scenario we chose, but different baselines would yield the same qualitative result as long as relative emission patterns are similar.
} 


\section{Acknowledgements}

We acknowledge support for this research under the European Union FP7 project "Impacts Quantification of Global Changes (GLOBAL-IQ)," grant agreement No.: 266992. Ana-Maria Vasilache-Freudenthaler provided excellent research assistance. This paper has benefited from the comments and suggestions by Richard Baldwin, Peter Egger, Rikard Forslid, Henri de Groot, Thomas Hertel, Douglas Nelson, Karen Helen Ulltveit-Moe, and participants at the 16th Annual Conference on Global Economic Analysis in Shanghai (June 2013) and the Annual Global IQ meeting in Rome (September 2013), ETSG Fifteenth Annual Conference in Birmingham (September 2013) and the Fifth Villars Research Workshop on International Trade (February 2014).

\section{References}

Astill, J. (2012). "The Melting North," The Economist, June 14th.

Barents Observer (2011a). "First Supertanker along Northern Sea Route," August 24.

Barents Observer (2011b). "Speed Record on Northern Sea Route," August 17.

Caliendo, L. and F. Parro (2015). "Estimates of the Trade and Welfare Effects of NAFTA," Review of Economic Studies, 82(1), 1-44.

Clark, X., D. Dollar, and A. Micco (2004). "Port Efficiency, Maritime Transport Costs and Bilateral Trade," Journal of Development Economics, 75(2), 417-450.

Comiso, J. C. (2012). "Large Decadal Decline of the Arctic Multiyear Ice Cover," Journal of Climate, 25(4), 1176-1193.

Costinot, A. and A. Rodríguez-Clare (2013). "Trade Theory with Numbers: Quantifying the Consequences of Globalization," in Handbook of International Economics, ed. by G. Gopinath, E. Helpman, and K. Rogoff, North Holland, vol. 4.

Day, J. J., J. C. Hargreaves, J. D. Annan, and A. Abe-Ouchi (2012). "Sources of Multi-decadal Variability in Arctic Sea Ice Extent," Environmental Research Letters, $7(3)$.

De Benedictis, L. and L. Tajoli (2011). "The World Trade Network," World Economy, 34(8), 1417-1454.

de Sousa, J., T. Mayer, and S. Zignago (2012). "Market Access in Global and Regional Trade," Regional Science and Urban Economics, 42(6), 1037-1052. 
Dixon, P. and D. Jorgenson, eds. (2013). Handbook of Computable General Equilibrium Modeling, vol. 1, Elsevier: North Holland.

Dür, A., L. Baccini, and M. Elsig (2014). "The Design of International Trade Agreements: Introducing a New Database," Review of International Organizations, Forthcoming.

Easley, D. and J. Kleinberg (2010). Networks, Crowds, and Markets: Reasoning about a Highly Connected World, Cambridge, UK: Cambridge University Press.

Eaton, J. and S. Kortum (2002). "Technology, Geography and Trade," Econometrica, 70(5), 1741-1779.

Egger, P., M. Larch, K. E. Staub, and R. Winkelmann (2011). "The Trade Effects of Endogenous Preferential Trade Agreements," American Economic Journal: Economic Policy, 3(3), 113-143.

Egger, P. and S. Nigai (2014). "Structural Gravity with Dummies Only," Working paper, ETH Zurich.

Egger, P. and S. Nigai (2015). "World-Trade Growth Accounting," Working paper, ETH Zurich.

Fink, C., A. Mattoo, and I. C. Neagu (2000). "Trade in International Maritime Services: How Much Does Policy Matter?" World Bank Economic Review, 16(1), $81-108$.

Francois, J. F. (2000). "Assessing the Results of General Equilibrium Studies of Multilateral Trade Negotiations," Working paper, UNCTAD, Geneva.

Francois, J. F., M. Manchin, H. Norberg, O. Pindyuk, and P. Tomberger (2013). "Reducing Trans-Atlantic Barriers to Trade and Investment," Final project report, Centre for Economic Policy Research (CEPR), London.

Francois, J. F., H. van Mijl, and F. van Tongeren (2005). "The Doha Round and Developing Countries," Economic Policy, 20(42), 349-391.

Hanoch, G. (1975). "Production and Demand Models in Direct or Indirect Implicit Additivity," Econometrica, 43, 395-419.

Head, K. and T. Mayer (2010). "Illusory Border Effects: Distance Mismeasurement Inflates Estimates of Home Bias in Trade," in The Gravity Model in International Trade: Advances and Applications, ed. by S. Brakman and P. van Bergeijk, Cambridge: Cambridge University Press. 
Hertel, T. (2013). "Global Applied General Equilibrium Analysis Using the Global Trade Analysis Project Framework," in Handbook of Computable General Equilibrium Modeling, ed. by P. Dixon and D. Jorgenson, Amsterdam: Elsevier: North Holland.

Huff, K., K. Hanslow, T. Hertel, and M. Tsigas (1997). "GTAP Behavioral Parameters," in Global Trade Analysis: Modelling and Applications, ed. by T. Hertel, Cambridge University Press, chap. 4, 124-148.

Hummels, D. and G. Schaur (2013). "Time as a Trade Barrier," American Economic Review, 103(7), 2935-2959.

Humpert, M. and A. Raspotnik (2012). "The Future of Arctic Shipping," Port Technology International, 55, 10-11.

IIASA (2012). "Supplementary Note for the SSP Data Sets," Database and documentation SSP2, International Institute for Applied Systems Analysis (IIASA).

Kattsov, V. M., V. E. Ryabinin, J. E. Overland, M. C. Serreze, M. Visbeck, J. E. Walsh, W. Meier, and X. Zhang (2010). "Arctic Sea Ice Change: A Grand Challenge of Climate Science," Journal of Glaciology, 56, 1115-1121.

Kay, J. E., M. M. Holland, and A. Jahn (2011). "Inter-annual to Multi-decadal Arctic Sea Ice Extent Trends in a Warming World," Geophysical Research Letters, 38, L15708.

Kerr, R. A. (2012). "Experts Agree Global Warming Is Melting the World Rapidly," Science, 338, 1138.

Khon, V., I. I. Mokhov, M. Latif, V. A. Semenov, and W. Park (2010). "Perspectives of Northern Sea Route and Northwest Passage in the Twenty-first Century," Climate Change, 100(3-4), 757-768.

Kinnard, C., C. M. Zdanowicz, D. A. Fisher, E. Isaksson, A. de Vernal, and L. G. Thompson (2011). "Reconstructed Changes in Arctic Sea Ice Over the Past 1450 Years," Nature, 479, 509-513.

Lasserre, F. and S. Pelletier (2011). "Polar Super Seaways? Maritime Transport in the Arctic: An Analysis of Shipowners' Intentions," Journal of Transport Geography, $19,1465-1473$.

Lee, H.-W. (2008). "The Combustion-based CO2 Emissions Data for GTAP Version 7 Data Base," GTAP database documentation, Global Trade Analysis Project. 
Levchenko, A. and J. Zhang (2015). "The Evolution of Comparative Advantage: Measurement and Implications," Working paper, University of Michigan.

Limão, N. and A. J. Venables (2001). "Infrastructure, Geographical Disadvantage, Transport Costs and Trade," World Bank Economic Review, 15(3), 451-479.

Liu, M. and J. Kronbak (2010). "The Potential Economic Viability of Using the Northern Sea Route (NSR) as an Alternative Route Between Asia and Europe," Journal of Transport Geography, 18, 434-444.

Mayer, T. and S. Zignago (2011). "Notes on CEPIIs Distances Measures: The GeoDist Database," Document de Travail No. 2011-25, CEPII.

McDougall, R. and A. Golub (2007). "GTAP E: A Revised Energy Environmental Version of the GTAP Model," GTAP Research Memorandum 15, Global Trade Analysis Project.

Micco, A. and N. Pérez (2002). "Determinants of Maritime Transport Costs," Research Department Working Paper 441, Inter-American Development Bank.

Narayanan, B., A. Aguiar, and R. McDougall, eds. (2012). Global Trade, Assistance, and Production: The GTAP 8 Data Base, Purdue University: Center for Global Trade Analysis.

OECD (2008). "Clarifying Trade Costs in Maritime Transport," Report TAD/TC/WP(2008)10, Working Party of the Trade Committee, OECD, Paris.

OECD (2011). "Maritime Transport Costs and Their Impacts on Trade," Report TAD/TC/WP(2009)7/REV1, Working Party of the Trade Committee, OECD, Paris.

OECD (2013). "Trade Costs: What Have We Learned? A Synthesis Report," OECD Trade Policy Paper 150. TAD/TC/WP(2013)3/FINAL, Working Party of the Trade Committee, OECD, Paris.

O'Neill, B., T. Carter, K. Ebi, J. Edmonds, S. Hallegatte, E.Kemp-Benedict, E.Kriegler, L. Mearns, R. Moss, K. Riahi, B. van Ruijven, and D. van Vuuren (2012). "Workshop on The Nature and Use of New Socioeconomic Pathways for Climate Change Research," Final meeting report, National Center for Atmospheric Research (NCAR).

Radelet, S. and J. D. Sachs (1998). "Shipping Costs, Manufactured Exports, and Economic Growth," Presented at the American Economics Association annual meeting, January 1998, Earth Institute, Columbia University. 
Rampal, P., J. Weiss, C. Dubois, and J.-M. Campin (2011). "IPCC Climate Models Do Not Capture Arctic Sea Ice Drift Acceleration: Consequences in Terms of Projected Sea Ice Thinning and Decline," Journal of Geophysical Research: Oceans, 116(C8).

Rodrigues, J. M. (2008). "The Rapid Decline of the Sea Ice in the Russian Arctic," Cold Regions Science and Technology, 54, 124-142.

Rogers, T. S., J. E. Walsh, M. Leonawicz, and M. Lindgren (2015). "Arctic Sea Ice: Use of Observational Data and Model Hindcasts to Refine Future Projections of Ice Extent," Polar Geography, 38(1), 22-41.

Rutherford, T. F. and S. V. Paltsev (2000). "GTAPinGAMS and GTAP-EG: Global Datasets for Economic Research and Illustrative Models," Working paper, University of Colorado, Boulder.

Santos Silva, J. and S. Tenreyro (2006). "The Log of Gravity," Review of Economics and Statistics, 88(4), 641-658.

Santos Silva, J. and S. Tenreyro (2011). "Further Simulation Evidence on the Performance of the Poisson Pseudo-maximum Likelihood Estimator," Economics Letters, $112(2), 220-222$.

Schøyen, H. and S. Bråthen (2011). "The Northern Sea Route versus the Suez Canal: Cases from bulk shipping," Journal of Transport Geography, 19, 977-983.

Shepherd et al. (2012). "A Reconciled Estimate of Ice-Sheet Mass Balance," Science, $338,1183-1189$.

Shikher, S. (2012). "Putting Industries into the Eaton-Kortum Model," The Journal of International Trade and Economic Development, 21(6), 807-837.

Slezak, M. (2013). "Antarctic Ice Melting Faster than in Past 1000 Years," Nature Geoscience, 2913.

Stammerjohn, S., R. Massom, D. Rind, and D. Martinson (2012). "Regions of Rapid Sea Ice Change: An Inter-hemispheric Seasonal Comparison," Geophysical Research Letters, 39(6).

Stephenson, S. R., L. C. Smith, L. W. Brigham, and J. A. Agnew (2013). "Projected 21st-century Changes to Arctic Marine Access," Climate Change, 118, 885-899.

Stroeve, J. C., M. C. Serreze, M. M. Holland, J. E. Kay, J. Malanik, and A. P. Barrett (2012). "The Arctic's Rapidly Shrinking Sea Ice Cover: A Research Synthesis," 
Climate Change, 110, 1005-1027.

Teorell, J., C. Dahlström, and S. Dahlberg (2011). "The QoG Expert Survey Dataset," Report, University of Gothenburg: the Quality of Government Institute (QOG).

Vavrus, S. J., M. M. Holland, A. Jahn, D. A. Bailey, and B. A. Blazey (2012). "Twenty-first-century Arctic Climate Change in CCSM4," Journal of Climate, 25(8), 2696-2710.

Verny, J. and C. Grigentin (2009). "Container Shipping on the Northern Sea Route," International Journal of Production Economics, 122, 107-117.

Wang, M. and J. E. Overland (2009). "A Sea Ice Free Summer Arctic Within 30 Years?" Geophysical Research Letters, 36, L07502.

Wang, M. and J. E. Overland (2012). "A Sea Ice Free Summer Arctic within 30 Years: An Update from CMIP5 Models," Geophysical Research Letters, 39(18).

Zeitsch, J. F., R. McDougall, P. Jomini, A. Welsh, J. Hambley, S. Brown, and J. Kelly (1991). "SALTER: A General Equilibrium Model of the World Economy," SALTER Working Paper 4, Industry Commission Australia.

Zhou, M. (2011). "Intensification of Geo-cultural Homophily in Global Trade: Evidence from the Gravity Model," Social Science Research, 40(1), 193-209. 


\section{A Appendix}

Table 7: Robustness check: measures of distance and dummies model only

\begin{tabular}{|c|c|c|c|c|c|c|c|c|c|}
\hline & \multicolumn{3}{|c|}{ B_t } & \multicolumn{3}{|c|}{ CRP } & \multicolumn{3}{|c|}{ ELE } \\
\hline & $\begin{array}{l}\text { shipping } \\
\text { distance }\end{array}$ & $\begin{array}{c}\text { CEPII } \\
\text { distance }\end{array}$ & $\begin{array}{c}\text { no } \\
\text { distance }\end{array}$ & $\begin{array}{l}\text { shipping } \\
\text { distance }\end{array}$ & $\begin{array}{c}\text { CEPII } \\
\text { distance }\end{array}$ & $\begin{array}{c}\text { no } \\
\text { distance }\end{array}$ & $\begin{array}{l}\text { shipping } \\
\text { distance }\end{array}$ & $\begin{array}{c}\text { CEPII } \\
\text { distance }\end{array}$ & $\begin{array}{c}\text { no } \\
\text { distance }\end{array}$ \\
\hline$N$ & 11,863 & 11,863 & 11,863 & 11,863 & 11,863 & 11,863 & 11,863 & 11,863 & 11,863 \\
\hline pseudo $R^{2}$ & 0.9831 & 0.9660 & 0.4902 & 0.9673 & 0.9545 & 0.6572 & 0.9483 & 0.9398 & 0.7698 \\
\hline \multirow[t]{3}{*}{$\mathrm{BIC}$} & $1.2 \mathrm{e}+05$ & $3.5 \mathrm{e}+05$ & $6.7 \mathrm{e}+06$ & $2.1 \mathrm{e}+06$ & $2.9 \mathrm{e}+06$ & $2.3 \mathrm{e}+07$ & $1.5 \mathrm{e}+06$ & $1.7 \mathrm{e}+06$ & $7.0 \mathrm{e}+06$ \\
\hline & & MTL & & & MVH & & & OGD & \\
\hline & $\begin{array}{l}\text { shipping } \\
\text { distance }\end{array}$ & $\begin{array}{c}\text { CEPII } \\
\text { distance }\end{array}$ & $\begin{array}{c}\text { no } \\
\text { distance }\end{array}$ & $\begin{array}{l}\text { shipping } \\
\text { distance }\end{array}$ & $\begin{array}{c}\text { CEPII } \\
\text { distance }\end{array}$ & $\begin{array}{c}\text { no } \\
\text { distance }\end{array}$ & $\begin{array}{l}\text { shipping } \\
\text { distance }\end{array}$ & $\begin{array}{c}\text { CEPII } \\
\text { distance }\end{array}$ & $\begin{array}{c}\text { no } \\
\text { distance }\end{array}$ \\
\hline$N$ & 11,863 & 11,863 & 11,863 & 11,863 & 11,863 & 11,863 & 11,863 & 11,863 & 11,863 \\
\hline pseudo R2 & 0.9734 & 0.9536 & 0.6407 & 0.9564 & 0.9554 & 0.6735 & 0.9812 & 0.9633 & 0.5968 \\
\hline \multirow[t]{3}{*}{$\mathrm{BIC}$} & $1.7 \mathrm{e}+06$ & $3.0 \mathrm{e}+06$ & $2.4 \mathrm{e}+07$ & $1.6 \mathrm{e}+06$ & $1.6 \mathrm{e}+06$ & $1.3 \mathrm{e}+07$ & $1.7 \mathrm{e}+06$ & $3.5 \mathrm{e}+06$ & $3.9 \mathrm{e}+07$ \\
\hline & & $\mathrm{OMC}$ & & & PRA & & & PRE & \\
\hline & $\begin{array}{l}\text { shipping } \\
\text { distance }\end{array}$ & $\begin{array}{c}\text { CEPII } \\
\text { distance }\end{array}$ & $\begin{array}{c}\text { no } \\
\text { distance } \\
\end{array}$ & $\begin{array}{l}\text { shipping } \\
\text { distance }\end{array}$ & $\begin{array}{c}\text { CEPII } \\
\text { distance }\end{array}$ & $\begin{array}{c}\text { no } \\
\text { distance }\end{array}$ & $\begin{array}{l}\text { shipping } \\
\text { distance }\end{array}$ & $\begin{array}{c}\text { CEPII } \\
\text { distance }\end{array}$ & $\begin{array}{c}\text { no } \\
\text { distance } \\
\end{array}$ \\
\hline$N$ & 11,863 & 11,863 & 11,863 & 11,863 & 11,863 & 11,863 & 11,863 & 11,863 & 11,863 \\
\hline pseudo R2 & 0.9675 & 0.9500 & 0.7274 & 0.9796 & 0.9700 & 0.5013 & 0.9262 & 0.9009 & 0.6320 \\
\hline \multirow[t]{3}{*}{$\mathrm{BIC}$} & $2.4 \mathrm{e}+06$ & $3.8 \mathrm{e}+06$ & $2.1 \mathrm{e}+07$ & $8.5 \mathrm{e}+05$ & $1.3 \mathrm{e}+06$ & $2.3 \mathrm{e}+07$ & $2.1 \mathrm{e}+06$ & $2.8 \mathrm{e}+06$ & $1.1 \mathrm{e}+07$ \\
\hline & & PRF & & & $\mathrm{P} \_\mathrm{C}$ & & & & \\
\hline & $\begin{array}{l}\text { shipping } \\
\text { distance }\end{array}$ & $\begin{array}{c}\text { CEPII } \\
\text { distance }\end{array}$ & $\begin{array}{c}\text { no } \\
\text { distance }\end{array}$ & $\begin{array}{l}\text { shipping } \\
\text { distance }\end{array}$ & $\begin{array}{c}\text { CEPII } \\
\text { distance }\end{array}$ & $\begin{array}{c}\text { no } \\
\text { distance }\end{array}$ & $\begin{array}{l}\text { shipping } \\
\text { distance }\end{array}$ & $\begin{array}{c}\text { CEPII } \\
\text { distance }\end{array}$ & $\begin{array}{c}\text { no } \\
\text { distance }\end{array}$ \\
\hline$N$ & 11,863 & 11,863 & 11,863 & 11,863 & 11,863 & 11,863 & & & \\
\hline pseudo R2 & 0.9829 & 0.9621 & 0.4559 & 0.9647 & 0.9389 & 0.5144 & & & \\
\hline $\mathrm{BIC}$ & $9.2 \mathrm{e}+05$ & $2.2 \mathrm{e}+06$ & $3.3 e+07$ & $9.4 \mathrm{e}+05$ & $1.7 \mathrm{e}+06$ & $1.4 \mathrm{e}+07$ & & & \\
\hline
\end{tabular}

Notes: PPML estimates, all including source and destination fixed effects and variations on distance controls. Significance levels: ${ }^{* * *} p<0.01,{ }^{* *} p<0.05,{ }^{*} p<0.1$. Sector codes: B_T beverages \& tobacco; CRP chemicals, rubber, plastics; ELE electrical machinery; MTL metals; MVH motor vehicles; OGD other goods; OMC other machinery; PRA primary agriculture; PRE primary energy; PRF processed foods; $\mathrm{P} \_\mathrm{C}$ petrochemicals. 
Table 8: Sectoral description and aggregation

\begin{tabular}{|c|c|c|c|}
\hline Sector & Code & Sector description & Aggregated GTAP sectors \\
\hline 1 & PRA & Primary agriculture & $\begin{array}{l}\text { OSD (oil seeds), C_B (sugar cane), PFB (plant-based } \\
\text { fibers), OCR (crops nec), CTL (cattle), OAP (animal prods } \\
\text { nec), RMK (raw milk), WOL (wool), FSH (fishing), FRS } \\
\text { (forestry) }\end{array}$ \\
\hline 2 & PRE & Primary energy & COA (coal), OIL (oil), GAS (gas), OMN (Minerals nec) \\
\hline 3 & PRF & Processed foods & $\begin{array}{l}\text { PDR (paddy rice), WHT (wheat), GRO (cereal grains nec), } \\
\text { V_F (vegetables \& fruits), CMT (bovine meat prods), OMT } \\
\text { (Meat prods nec), VOL (vegetable oils), MIL (diary prod), } \\
\text { PCR (processed rice), SGR (sugar), OFD (food products } \\
\text { nec) }\end{array}$ \\
\hline 4 & $\mathrm{~B} \_\mathrm{T}$ & Beverages and tobacco & B_T (beverages \& tobacco products) \\
\hline 5 & $\mathrm{P} \_\mathrm{C}$ & Petrochemicals & $\begin{array}{l}\mathrm{P} \_\mathrm{C} \text { (Petroleum and coal products), GDT (gas manufacture } \\
\text { and distribution) }\end{array}$ \\
\hline 6 & CRP & Chemicals, rubber, plactics & CRP (Chemical, rubber and plastic products) \\
\hline 7 & MTL & Metals & $\begin{array}{l}\text { I_S (ferrous metals), NFM (metals nec), FMP (metal prod- } \\
\text { ucts) }\end{array}$ \\
\hline 8 & MVH & Motor vehicles & MVH (motor vehicles and parts) \\
\hline 9 & ELE & Electrical machinery & ELE (electronic equipment) \\
\hline 10 & $\mathrm{OMC}$ & Other machinery & OME (machinery and equipment nec) \\
\hline 11 & OGD & Other goods & $\begin{array}{l}\text { TEX (textiles), WAP (wearing apparel), LEA (leather prod- } \\
\text { ucts), LUM (wood products), PPP (paper products and } \\
\text { publishing), OTN (transport equipment nec), NMM (min- } \\
\text { eral products nec), OMF (manufactures nec) }\end{array}$ \\
\hline 12 & TRA & Transport & $\begin{array}{l}\text { OTP (transport nec), WTP (water transport), ATP (air } \\
\text { transport) }\end{array}$ \\
\hline 13 & $\mathrm{CNS}$ & Construction & CNS (construction) \\
\hline 14 & PSR & Producer services & $\begin{array}{l}\text { ELY (electricity), WTR (water), TRD (trade), CMN (com- } \\
\text { munication), OFI (financial services nec), ISR (insurance), } \\
\text { OBS (Business services nec) }\end{array}$ \\
\hline 15 & CSR & Consumer services & ROS (recreational and other services), DWE (dwellings) \\
\hline 16 & OSG & Public services & OSG (Public Administration, Defense, Education, Health) \\
\hline
\end{tabular}


Table 9: Country sample

\begin{tabular}{|c|c|c|c|c|c|c|c|c|}
\hline & Code & Country & & Code & Country & & Code & Country \\
\hline 1 & aus & Australia & 38 & aut & Austria & 75 & bhr & Bahrain \\
\hline 2 & nzl & New Zealand & 39 & bel & Belgium & 76 & irn & Iran \\
\hline 3 & $\operatorname{chn}$ & China & 40 & cyp & Cyprus & 77 & isr & Israel \\
\hline 4 & jpn & Japan & 41 & cze & Czech Republic & 78 & kwt & Kuwait \\
\hline 5 & kor & South Korea & 42 & dnk & Denmark & 79 & omn & Oman \\
\hline 6 & mng & Mongolia & 43 & est & Estonia & 80 & qat & Qatar \\
\hline 7 & twn & Taiwan & 44 & fin & Finland & 81 & sau & Saudi Arabia \\
\hline 8 & idn & Indonesia & 45 & fra & France & 82 & tur & Turkey \\
\hline 9 & mys & Malaysia & 46 & deu & Germany & 83 & are & United Arab Emirates \\
\hline 10 & phl & Philippines & 47 & $\operatorname{grc}$ & Greece & 84 & egy & Egypt \\
\hline 11 & $\operatorname{sgp}$ & Singapore & 48 & hun & Hungary & 85 & mar & Morocco \\
\hline 12 & tha & Thailand & 49 & irl & Ireland & 86 & tun & Tunisia \\
\hline 13 & vnm & Viet Nam & 50 & ita & Italy & 87 & ben & Benin \\
\hline 14 & bgd & Bangladesh & 51 & lva & Latvia & 88 & bfa & Burkina Faso \\
\hline 15 & ind & India & 52 & ltu & Lithuania & 89 & $\mathrm{cmr}$ & Cameroon \\
\hline 16 & $\mathrm{npl}$ & Nepal & 53 & $\operatorname{lux}$ & Luxembourg & 90 & $\operatorname{civ}$ & Cote d'Ivoire \\
\hline 17 & pak & Pakistan & 54 & mlt & Malta & 91 & gha & Ghana \\
\hline 18 & lka & Sri Lanka & 55 & nld & Netherlands & 92 & gin & Guinea \\
\hline 19 & can & Canada & 56 & pol & Poland & 93 & nga & Nigeria \\
\hline 20 & usa & United States & 57 & prt & Portugal & 94 & sen & Senegal \\
\hline 21 & mex & Mexico & 58 & svk & Slovakia & 95 & $\operatorname{tgo}$ & Togo \\
\hline 22 & $\arg$ & Argentina & 59 & svn & Slovenia & 96 & eth & Ethiopia \\
\hline 23 & bol & Bolivia & 60 & esp & Spain & 97 & ken & Kenya \\
\hline 24 & bra & Brazil & 61 & swe & Sweden & 98 & mdg & Madagascar \\
\hline 25 & chl & Chile & 62 & gbr & United Kingdom & 99 & mwi & Malawi \\
\hline 26 & $\mathrm{col}$ & Colombia & 63 & che & Switzerland & 100 & mus & Mauritius \\
\hline 27 & ecu & Ecuador & 64 & nor & Norway & 101 & moz & Mozambique \\
\hline 28 & pry & Paraguay & 65 & alb & Albania & 102 & rwa & Rwanda \\
\hline 29 & per & Peru & 66 & bgr & Bulgaria & 103 & tza & Tanzania \\
\hline 30 & ury & Uruguay & 67 & blr & Belarus & 104 & uga & Uganda \\
\hline 31 & ven & Venezuela & 68 & hrv & Croatia & 105 & $\mathrm{zmb}$ & Zambia \\
\hline 32 & cri & Costa Rica & 69 & rou & Romania & 106 & zwe & Zimbabwe \\
\hline 33 & gtm & Guatemala & 70 & rus & Russian Federation & 107 & bwa & Botswana \\
\hline 34 & hnd & Honduras & 71 & $\mathrm{ukr}$ & Ukraine & 108 & nam & Namibia \\
\hline 35 & nic & Nicaragua & 72 & arm & Armenia & 109 & zaf & South Africa \\
\hline 36 & pan & Panama & 73 & aze & Azerbaijan & 110 & row & Rest of the World \\
\hline 37 & slv & El Salvador & 74 & geo & Georgia & & & \\
\hline
\end{tabular}


Table 10: Northeast Asia, changes in trade volumes for goods for selected countries, percentage changes

\begin{tabular}{|c|c|c|c|c|c|c|}
\hline & \multicolumn{2}{|c|}{ China } & \multicolumn{2}{|c|}{ Japan } & \multicolumn{2}{|c|}{ South Korea } \\
\hline & exports & imports & exports & imports & exports & imports \\
\hline Austria & 13.29 & 14.93 & 16.65 & 23.30 & 11.40 & 16.54 \\
\hline Belgium & 12.50 & 12.71 & 17.11 & 15.95 & 15.68 & 16.44 \\
\hline Bulgaria & -1.82 & 0.75 & -1.48 & 0.28 & -1.41 & 0.10 \\
\hline Croatia & -1.37 & 0.58 & -1.36 & -0.10 & -0.81 & -0.19 \\
\hline Czech Republic & 8.25 & 17.19 & 17.03 & 26.17 & 11.05 & 21.61 \\
\hline Denmark & 11.94 & 15.29 & 14.88 & 19.50 & 11.03 & 16.63 \\
\hline Estonia & 10.83 & 16.69 & 12.09 & 23.97 & 12.82 & 19.86 \\
\hline Finland & 11.86 & 12.63 & 15.92 & 23.08 & 11.76 & 17.11 \\
\hline France & 1.47 & 4.38 & 10.38 & 10.09 & 4.50 & 8.08 \\
\hline Germany & 10.94 & 12.12 & 15.70 & 16.37 & 8.50 & 15.78 \\
\hline Greece & -1.13 & 0.37 & -0.66 & -0.17 & -0.86 & 0.07 \\
\hline Hungary & -2.17 & 0.59 & -1.56 & 0.96 & -1.42 & 0.56 \\
\hline Ireland & 12.18 & 14.39 & 16.62 & 18.32 & 74.44 & 17.16 \\
\hline Italy & -1.52 & 1.12 & -1.28 & 0.18 & -0.96 & 0.38 \\
\hline Latvia & 11.42 & 20.67 & 12.75 & 30.56 & 12.21 & 22.84 \\
\hline Lithuania & 11.21 & 12.12 & 15.80 & 24.28 & 14.06 & 17.38 \\
\hline Netherlands & 11.09 & 16.06 & 17.82 & 24.96 & 15.48 & 18.65 \\
\hline Poland & 11.15 & 14.70 & 14.17 & 22.41 & 10.16 & 18.21 \\
\hline Portugal & -0.69 & 1.09 & 6.35 & 8.80 & 4.49 & 5.58 \\
\hline Romania & -1.88 & 0.88 & -1.58 & 0.26 & -1.34 & 0.32 \\
\hline Slovakia & 7.72 & 6.74 & 15.52 & 13.22 & 9.73 & 17.58 \\
\hline Slovenia & -1.67 & 1.47 & -1.22 & 0.53 & -0.81 & 1.18 \\
\hline Spain & -0.73 & 1.20 & 7.01 & 8.31 & 3.36 & 4.29 \\
\hline Sweden & 13.93 & 14.72 & 15.60 & 22.79 & 11.54 & 17.49 \\
\hline United Kingdom & 12.83 & 12.57 & 15.06 & 18.31 & 11.64 & 15.69 \\
\hline Norway & 12.70 & 13.63 & 15.85 & 22.98 & 5.75 & 17.22 \\
\hline Turkey & -1.40 & 0.37 & -1.14 & 0.11 & -0.83 & 0.03 \\
\hline United States & -0.81 & 0.43 & -0.67 & 0.03 & -0.32 & -0.11 \\
\hline
\end{tabular}


Table 11: Changes in trade values by region for selected countries, percentage changes

\begin{tabular}{|c|c|c|c|c|c|c|c|c|c|c|c|c|}
\hline \multirow[b]{3}{*}{ Total EU } & \multicolumn{3}{|c|}{ Austria } & \multicolumn{3}{|c|}{ Belgium } & \multicolumn{3}{|c|}{ Czech Republic } & \multicolumn{3}{|c|}{ France } \\
\hline & exports & imports & trade & exports & imports & trade & exports & imports & trade & exports & imports & trade \\
\hline & -0.5 & -0.5 & -0.5 & -0.3 & -0.7 & -0.5 & -0.1 & -0.9 & -0.4 & -0.5 & -0.2 & -0.3 \\
\hline South EU & 0.0 & -0.6 & -0.3 & 0.1 & -0.8 & -0.3 & 1.1 & -1.0 & 0.2 & -0.1 & -0.3 & -0.2 \\
\hline East EU & -0.7 & -0.2 & -0.5 & -0.7 & -0.8 & -0.7 & -0.4 & -0.5 & -0.4 & -0.9 & 0.3 & -0.2 \\
\hline NW EU & -0.7 & -0.6 & -0.7 & -0.4 & -0.7 & -0.6 & -0.4 & -1.1 & -0.7 & -0.9 & -0.2 & -0.5 \\
\hline NE Asia & 11.6 & 11.0 & 11.2 & 11.1 & 12.5 & 12.0 & 16.1 & 8.5 & 9.4 & 4.6 & 2.4 & 3.1 \\
\hline RoW & 0.2 & -0.9 & -0.2 & 0.2 & -1.1 & -0.5 & 1.3 & -1.7 & -0.1 & 0.2 & -0.5 & -0.1 \\
\hline \multirow[t]{3}{*}{ TOTAL } & 0.3 & 0.2 & 0.3 & 0.4 & 0.4 & 0.4 & 0.4 & 0.5 & 0.4 & 0.1 & 0.1 & 0.1 \\
\hline & \multicolumn{3}{|c|}{ Germany } & \multicolumn{3}{|c|}{ Greece } & \multicolumn{3}{|c|}{ Hungary } & \multicolumn{3}{|c|}{ Ireland } \\
\hline & exports & imports & trade & exports & imports & trade & exports & imports & trade & exports & imports & trade \\
\hline Total EU & -0.5 & -0.6 & -0.6 & -0.2 & 0.1 & 0.0 & -0.7 & -0.1 & -0.4 & -0.4 & -0.2 & -0.3 \\
\hline South EU & 0.0 & -0.7 & -0.3 & -0.2 & 0.0 & 0.0 & 0.2 & -0.4 & -0.1 & -0.1 & -0.1 & -0.1 \\
\hline East EU & -1.0 & -0.6 & -0.8 & -0.5 & 0.3 & 0.0 & -0.7 & 0.3 & -0.3 & -0.7 & -0.2 & -0.5 \\
\hline NW EU & -0.7 & -0.6 & -0.7 & -0.2 & 0.1 & 0.0 & -1.1 & -0.2 & -0.7 & -0.6 & -0.2 & -0.4 \\
\hline NE Asia & 10.6 & 10.0 & 10.3 & 0.3 & -0.9 & -0.5 & 0.7 & -1.9 & -1.3 & 8.6 & 6.7 & 7.6 \\
\hline RoW & 0.3 & -1.1 & -0.4 & 0.0 & -0.1 & -0.1 & 0.5 & -0.4 & 0.1 & 0.2 & -0.8 & -0.1 \\
\hline \multirow[t]{3}{*}{ TOTAL } & 0.8 & 0.9 & 0.8 & -0.1 & -0.1 & -0.1 & -0.4 & -0.5 & -0.5 & 0.3 & 0.3 & 0.3 \\
\hline & \multicolumn{3}{|c|}{ Italy } & \multicolumn{3}{|c|}{ Netherlands } & \multicolumn{3}{|c|}{ Poland } & \multicolumn{3}{|c|}{ Portugal } \\
\hline & exports & imports & trade & exports & imports & trade & exports & imports & trade & exports & imports & trade \\
\hline Total EU & -0.5 & 0.1 & -0.2 & -0.2 & -0.7 & -0.4 & 0.1 & -1.3 & -0.5 & -0.4 & -0.1 & -0.2 \\
\hline South EU & -0.1 & -0.1 & -0.1 & 0.1 & -0.7 & -0.2 & 0.7 & -1.6 & -0.5 & -0.1 & -0.2 & -0.2 \\
\hline East EU & -0.9 & 0.5 & -0.2 & -0.6 & -0.5 & -0.5 & -0.1 & -1.0 & -0.5 & -0.9 & 0.6 & -0.1 \\
\hline NW EU & -0.7 & 0.0 & -0.3 & -0.3 & -0.7 & -0.5 & -0.2 & -1.3 & -0.7 & -0.6 & -0.1 & -0.3 \\
\hline NE Asia & 0.7 & -1.3 & -0.8 & 10.6 & 10.6 & 10.6 & 13.4 & 10.7 & 11.0 & 1.5 & 0.4 & 0.8 \\
\hline RoW & 0.2 & -0.2 & 0.0 & 0.2 & -1.1 & -0.4 & 0.7 & -1.3 & -0.4 & 0.2 & -0.2 & 0.0 \\
\hline \multirow[t]{3}{*}{ TOTAL } & -0.2 & -0.2 & -0.2 & 0.4 & 0.4 & 0.4 & 0.5 & 0.4 & 0.5 & -0.1 & -0.1 & -0.1 \\
\hline & \multicolumn{3}{|c|}{ Romania } & \multicolumn{3}{|c|}{ Spain } & \multicolumn{3}{|c|}{ Sweden } & \multicolumn{3}{|c|}{ United Kingdom } \\
\hline & exports & imports & trade & exports & imports & trade & exports & imports & trade & exports & imports & trade \\
\hline Total EU & -0.4 & 0.0 & -0.2 & -0.3 & 0.0 & -0.1 & -0.6 & -0.6 & -0.6 & -0.1 & -0.9 & -0.5 \\
\hline South EU & 0.1 & -0.3 & -0.1 & -0.2 & -0.1 & -0.1 & 0.1 & -0.7 & -0.3 & 0.2 & -0.7 & -0.4 \\
\hline East EU & -0.6 & 0.3 & -0.1 & -0.6 & 0.6 & 0.0 & -1.2 & -0.2 & -0.6 & -0.5 & -1.1 & -0.9 \\
\hline NW EU & -1.0 & -0.1 & -0.5 & -0.4 & 0.0 & -0.2 & -0.8 & -0.6 & -0.7 & -0.2 & -0.9 & -0.6 \\
\hline NE Asia & 0.6 & -1.7 & -1.3 & 1.7 & 0.1 & 0.6 & 11.6 & 11.7 & 11.6 & 8.1 & 11.3 & 10.4 \\
\hline RoW & 0.2 & -0.3 & 0.0 & 0.1 & -0.2 & -0.1 & 0.1 & -0.8 & -0.2 & 0.4 & -1.4 & -0.6 \\
\hline \multirow[t]{2}{*}{ TOTAL } & -0.3 & -0.3 & -0.3 & -0.1 & -0.1 & -0.1 & 0.5 & 0.6 & 0.5 & 0.7 & 0.6 & 0.6 \\
\hline & exports & $\begin{array}{l}\text { China } \\
\text { imports }\end{array}$ & trade & exports & $\begin{array}{l}\text { Japan } \\
\text { imports }\end{array}$ & trade & exports & $\begin{array}{l}\text { Korea } \\
\text { imports }\end{array}$ & trade & exports & $\begin{array}{l}\text { USA } \\
\text { imports }\end{array}$ & trade \\
\hline Total EU & 4.2 & 7.5 & 4.9 & 6.1 & 9.0 & 7.1 & 3.2 & 8.6 & 4.7 & -0.9 & 0.4 & -0.3 \\
\hline South EU & -1.1 & 1.0 & -0.6 & 1.5 & 1.6 & 1.5 & 0.2 & 0.8 & 0.5 & -0.3 & 0.2 & 0.0 \\
\hline East EU & 5.9 & 7.1 & 6.1 & 9.3 & 9.3 & 9.3 & 8.0 & 8.3 & 8.0 & -1.6 & 1.1 & -0.1 \\
\hline NW EU & 9.1 & 8.7 & 9.0 & 11.8 & 10.6 & 11.3 & 8.0 & 10.6 & 9.3 & -1.4 & 0.4 & -0.4 \\
\hline NE Asia & -0.4 & 0.2 & -0.1 & -0.2 & -0.3 & -0.3 & 0.2 & -0.4 & -0.1 & 0.3 & -0.6 & -0.3 \\
\hline RoW & -0.6 & 0.4 & -0.1 & -0.4 & 0.3 & 0.0 & -0.2 & 0.2 & 0.0 & 0.0 & 0.0 & 0.0 \\
\hline TOTAL & 0.9 & 1.1 & 1.0 & 0.9 & 0.9 & 0.9 & 0.7 & 0.7 & 0.7 & -0.2 & -0.1 & -0.1 \\
\hline
\end{tabular}

Notes: South EU is: Cyprus, Greece, Italy, Malta, Portugal and Spain. East EU is: Bulgaria, Czech Republic, Estonia, Hungary, Latvia, Lithuania, Poland, Romania, Slovakia and Slovenia. Northwestern EU is: Austria, Belgium, Denmark, Finland, France, Germany, Ireland, Luxembourg, the Netherlands, Sweden and the United Kingdom. Northeast Asia is: China, Japan, South Korea, Hong Kong and Taiwan.

Source: Own estimations using the GTAP database. 
Table 12: Sectoral changes in export sales to China for selected countries, percentage changes

\begin{tabular}{lrrrrrrrrrrrrr}
\hline & AUT & BEL & CZE & FRA & DEU & HUN & ITA & NLD & ESP & SWE & GBR & JPN & KOR \\
Sector: & & & & & & & & & & & & & \\
1 PRA & 11.5 & 10.8 & 10.2 & 3.3 & 11.5 & 0.3 & 0.3 & 10.8 & 0.6 & 15.1 & 11.1 & 0.4 & 0.6 \\
2 PRE & 10.9 & 5.7 & 6.2 & 4.0 & 8.6 & 0.2 & 0.2 & 7.6 & 0.7 & 8.0 & 6.9 & -0.1 & 0.0 \\
3 PRF & 19.9 & 18.5 & 18.1 & 5.9 & 19.8 & 1.0 & 0.6 & 19.6 & 1.3 & 24.4 & 18.2 & 0.2 & 0.8 \\
4 B_T & -1.4 & -0.2 & 0.1 & -0.4 & -1.2 & 0.2 & 0.2 & -1.1 & 0.1 & -1.8 & -2.0 & 0.1 & 0.2 \\
5 P_C & 17.8 & 22.2 & 15.2 & 6.0 & 22.5 & 0.6 & 0.5 & 24.2 & 1.3 & 19.9 & 38.1 & 0.2 & 0.4 \\
6 CRP & 11.9 & 14.6 & 15.2 & 3.8 & 12.8 & 0.8 & 0.6 & 14.1 & 1.3 & 11.6 & 12.3 & 0.2 & 0.3 \\
7 MTL & 18.1 & 15.2 & 17.3 & 5.2 & 16.3 & 1.5 & 1.1 & 18.1 & 1.6 & 16.6 & 15.0 & 0.0 & 0.2 \\
8 MVH & 5.9 & 6.2 & 7.3 & 1.7 & 5.8 & -0.2 & -0.3 & 6.8 & 0.1 & 6.1 & 5.9 & -0.6 & -0.4 \\
9 ELE & 19.5 & 18.1 & 20.9 & 5.5 & 15.5 & 2.3 & 2.1 & 16.7 & 2.6 & 15.7 & 17.6 & -0.2 & 0.5 \\
10 OMC & 18.9 & 20.6 & 22.8 & 6.1 & 18.8 & 2.8 & 2.3 & 20.6 & 2.9 & 19.4 & 19.8 & -0.2 & 0.3 \\
11 OGD & 16.9 & 15.8 & 18.2 & 6.0 & 17.0 & 1.2 & 0.9 & 14.2 & 1.5 & 19.3 & 17.3 & 0.2 & 0.3 \\
12 TSP & 0.4 & 0.4 & 0.7 & 0.4 & 0.4 & 0.6 & 0.4 & 0.5 & 0.4 & 0.4 & 0.5 & 0.1 & 0.1 \\
13 CNS & 0.8 & 0.9 & 1.3 & 0.8 & 0.9 & 1.1 & 0.9 & 1.0 & 0.8 & 0.8 & 1.1 & 0.1 & 0.1 \\
14 BUS & 0.6 & 0.5 & 0.9 & 0.5 & 0.6 & 0.7 & 0.6 & 0.6 & 0.5 & 0.6 & 0.7 & 0.1 & 0.1 \\
15 ROS & 1.5 & 1.1 & 2.9 & 1.8 & 1.9 & 2.5 & 2.0 & 2.0 & 1.8 & 1.8 & 2.1 & 0.2 & 0.3 \\
16 OSV & 0.5 & 0.1 & 0.8 & 0.6 & 0.4 & 0.9 & 0.7 & 0.5 & 0.6 & 0.5 & 0.6 & 0.2 & 0.1 \\
& & & & & & & & & & & &
\end{tabular}

Notes: The description of each sector is given in Table 8 and country codes are in Table 9

Source: Own estimations using the GTAP database. 
Table 13: Sectoral changes in export sales to Germany for selected countries, percentage changes

\begin{tabular}{lrrrrrrrrrrrrr}
\hline & AUT & BEL & CZE & FRA & HUN & ITA & NLD & ESP & SWE & GBR & CHN & JPN & KOR \\
Sector: & & & & & & & & & & & & & \\
1 PRA & -0.1 & -0.3 & -0.2 & 0.1 & 0.2 & 0.1 & 0.1 & 0.0 & -0.9 & 0.1 & 8.9 & 25.6 & 13.6 \\
2 PRE & 0.3 & 0.1 & 0.8 & 0.4 & 0.9 & 0.5 & 0.3 & 0.3 & 0.4 & 0.5 & 9.8 & 18.5 & 14.6 \\
3 PRF & 0.2 & 0.2 & 0.3 & 0.2 & 0.3 & 0.2 & 0.2 & 0.2 & 0.2 & 0.3 & 15.9 & 30.9 & 20.3 \\
4 B_T & 0.0 & 0.4 & 0.2 & -0.1 & 0.1 & 0.0 & 0.3 & -0.1 & -0.2 & 0.0 & -2.1 & -2.1 & -2.3 \\
5 P_C & -0.4 & -0.2 & 0.1 & -0.4 & -0.2 & -0.4 & -0.2 & -0.5 & -0.4 & -0.1 & 19.0 & 29.1 & 22.8 \\
6 CRP & -0.3 & 0.0 & 0.5 & -0.2 & 0.2 & -0.2 & 0.1 & -0.4 & -0.2 & 0.3 & 11.0 & 15.5 & 11.3 \\
7 MTL & 0.4 & 0.5 & 0.6 & 0.1 & 0.1 & 0.0 & 0.3 & 0.1 & 0.2 & 0.3 & 15.8 & 20.4 & 17.5 \\
8 MVH & -4.5 & -4.0 & -1.7 & -5.1 & -5.2 & -5.4 & -4.4 & -5.4 & -4.3 & -3.5 & 6.8 & 11.0 & 10.2 \\
9 ELE & -2.8 & -2.5 & -1.2 & -3.1 & -2.7 & -3.3 & -2.3 & -3.4 & -2.7 & -2.1 & 5.0 & 12.6 & 7.2 \\
10 OMC & -1.3 & -1.0 & -0.8 & -1.3 & -1.0 & -1.3 & -1.1 & -1.4 & -1.3 & -0.9 & 12.6 & 16.8 & 7.1 \\
11 OGD & 0.2 & 0.1 & 0.5 & 0.2 & 0.3 & 0.2 & 0.2 & 0.2 & 0.2 & 0.2 & 12.4 & 18.5 & 15.8 \\
12 TSP & 0.4 & 0.4 & 0.8 & 0.3 & 0.6 & 0.4 & 0.5 & 0.3 & 0.3 & 0.7 & -0.1 & -0.2 & -0.1 \\
13 CNS & 0.3 & 0.2 & 0.6 & 0.2 & 0.4 & 0.2 & 0.3 & 0.2 & 0.2 & 0.3 & -0.3 & -0.3 & -0.4 \\
14 BUS & -0.1 & -0.5 & 1.3 & 0.2 & 0.9 & 0.4 & 0.4 & 0.2 & 0.2 & 0.5 & -0.2 & -0.2 & -0.2 \\
15 ROS & 0.2 & -0.2 & 0.5 & 0.3 & 0.6 & 0.4 & 0.3 & 0.3 & 0.3 & 0.4 & -1.5 & -1.4 & -1.3 \\
16 OSV & 0.0 & 0.0 & 0.0 & 0.0 & 0.0 & 0.0 & 0.0 & 0.0 & 0.0 & 0.0 & -0.2 & -0.1 & -0.2 \\
& & & & & & & & & & & & \\
Simple average & -0.5 & -0.4 & 0.1 & -0.5 & -0.3 & -0.5 & -0.3 & -0.6 & -0.5 & -0.2 & 7.0 & 12.2 & 8.5
\end{tabular}

Notes: The description of each sector is given in Table 8 and country codes are in Table 9

Source: Own estimations using the GTAP database. 
Table 14: CGE results on GDP, real income and welfare

\begin{tabular}{|c|c|c|c|c|}
\hline & GDP index & Real Income & $\begin{array}{l}\text { Welfare } \\
\text { (per capita } \\
\text { utility) } \% \\
\text { changes }\end{array}$ & $\begin{array}{l}\text { Welfare } \\
\text { (equivalent } \\
\text { variation in } \\
\text { US } \$ \text { million) }\end{array}$ \\
\hline Austria & 0.19 & 0.09 & 0.20 & 1,062 \\
\hline Belgium & 0.49 & 0.44 & 0.53 & 3,460 \\
\hline Bulgaria & -0.04 & -0.16 & -0.05 & -49 \\
\hline Croatia & -0.02 & -0.12 & -0.03 & -20 \\
\hline Czech Republic & 0.38 & 0.10 & 0.34 & 1,182 \\
\hline Denmark & 0.21 & 0.19 & 0.27 & 1,101 \\
\hline Estonia & 0.46 & 0.26 & 0.42 & 157 \\
\hline Finland & 0.14 & 0.09 & 0.17 & 587 \\
\hline France & 0.05 & -0.05 & 0.05 & 1,794 \\
\hline Germany & 0.28 & 0.17 & 0.31 & 13,049 \\
\hline Greece & -0.02 & -0.09 & -0.02 & -83 \\
\hline Hungary & -0.10 & -0.30 & -0.14 & -242 \\
\hline Ireland & 0.25 & 0.19 & 0.30 & 900 \\
\hline Italy & -0.02 & -0.13 & -0.03 & -673 \\
\hline Latvia & 0.41 & 0.22 & 0.40 & 186 \\
\hline Lithuania & 0.28 & 0.06 & 0.24 & 163 \\
\hline Netherlands & 0.18 & 0.07 & 0.21 & 2,153 \\
\hline Poland & 0.28 & 0.00 & 0.24 & 1,985 \\
\hline Portugal & 0.01 & -0.11 & 0.00 & -5 \\
\hline Romania & -0.04 & -0.19 & -0.05 & -152 \\
\hline Slovakia & 0.48 & 0.15 & 0.39 & 591 \\
\hline Slovenia & -0.06 & -0.24 & -0.10 & -63 \\
\hline Spain & 0.02 & -0.08 & 0.01 & 189 \\
\hline Sweden & 0.14 & 0.05 & 0.17 & 1,313 \\
\hline United Kingdom & 0.24 & 0.05 & 0.23 & 7,489 \\
\hline Norway & 0.17 & 0.14 & 0.23 & 1,547 \\
\hline Turkey & -0.03 & -0.14 & -0.04 & -686 \\
\hline China & 0.14 & 0.24 & 0.16 & 38,519 \\
\hline Japan & 0.11 & 0.20 & 0.13 & 8,142 \\
\hline Korea & 0.24 & 0.32 & 0.26 & 4,881 \\
\hline United States & 0.00 & -0.04 & 0.00 & $-1,021$ \\
\hline Total (World) & 0.06 & 0.05 & 0.07 & 88,107 \\
\hline
\end{tabular}

Source: Own estimations using the GTAP database. 
Table 15: CGE results for the labour market, real wages and total employment changes for three skill levels, percentage changes

\begin{tabular}{|c|c|c|c|c|c|c|c|c|c|}
\hline & \multicolumn{6}{|c|}{ Changes in real wages } & \multicolumn{3}{|c|}{$\begin{array}{l}\text { Changes in total employment } \\
\text { flexible labour supply }\end{array}$} \\
\hline & low skill & med skill & high skill & low skill & med skill & high skill & low skill & med skill & high skill \\
\hline Austria & 0.21 & 0.17 & 0.19 & 0.21 & 0.17 & 0.19 & 0.04 & 0.03 & 0.04 \\
\hline Belgium & 0.64 & 0.52 & 0.57 & 0.58 & 0.48 & 0.53 & 0.12 & 0.10 & 0.11 \\
\hline Bulgaria & -0.08 & -0.06 & -0.07 & -0.08 & -0.06 & -0.07 & -0.02 & -0.01 & -0.01 \\
\hline Croatia & -0.05 & -0.05 & -0.05 & -0.05 & -0.05 & -0.05 & -0.01 & -0.01 & -0.01 \\
\hline Czech Republic & 0.24 & 0.24 & 0.25 & 0.24 & 0.23 & 0.24 & 0.05 & 0.05 & 0.05 \\
\hline Denmark & 0.35 & 0.25 & 0.26 & 0.33 & 0.24 & 0.26 & 0.07 & 0.05 & 0.05 \\
\hline Estonia & 0.44 & 0.36 & 0.41 & 0.40 & 0.33 & 0.37 & 0.08 & 0.07 & 0.07 \\
\hline Finland & 0.19 & 0.15 & 0.14 & 0.18 & 0.14 & 0.13 & 0.04 & 0.03 & 0.03 \\
\hline France & 0.07 & 0.04 & 0.04 & 0.07 & 0.04 & 0.04 & 0.01 & 0.01 & 0.01 \\
\hline Germany & 0.33 & 0.27 & 0.28 & 0.32 & 0.26 & 0.27 & 0.06 & 0.05 & 0.05 \\
\hline Greece & -0.01 & -0.03 & -0.04 & -0.01 & -0.03 & -0.04 & 0.00 & -0.01 & -0.01 \\
\hline Hungary & -0.21 & -0.15 & -0.16 & -0.19 & -0.14 & -0.15 & -0.04 & -0.03 & -0.03 \\
\hline Ireland & 0.31 & 0.23 & 0.29 & 0.30 & 0.23 & 0.28 & 0.06 & 0.05 & 0.06 \\
\hline Italy & -0.03 & -0.04 & -0.03 & -0.02 & -0.03 & -0.03 & 0.00 & -0.01 & -0.01 \\
\hline Latvia & 0.29 & 0.32 & 0.31 & 0.28 & 0.30 & 0.30 & 0.06 & 0.06 & 0.06 \\
\hline Lithuania & 0.25 & 0.20 & 0.20 & 0.23 & 0.19 & 0.19 & 0.05 & 0.04 & 0.04 \\
\hline Netherlands & 0.24 & 0.21 & 0.23 & 0.24 & 0.20 & 0.23 & 0.05 & 0.04 & 0.05 \\
\hline Poland & 0.16 & 0.16 & 0.18 & 0.15 & 0.15 & 0.17 & 0.03 & 0.03 & 0.03 \\
\hline Portugal & -0.02 & -0.01 & -0.02 & -0.02 & -0.01 & -0.01 & 0.00 & 0.00 & 0.00 \\
\hline Romania & -0.06 & -0.08 & -0.08 & -0.06 & -0.07 & -0.07 & -0.01 & -0.01 & -0.01 \\
\hline Slovakia & 0.24 & 0.27 & 0.30 & 0.23 & 0.25 & 0.28 & 0.05 & 0.05 & 0.06 \\
\hline Slovenia & -0.09 & -0.11 & -0.12 & -0.09 & -0.10 & -0.11 & -0.02 & -0.02 & -0.02 \\
\hline Spain & 0.02 & 0.00 & 0.00 & 0.02 & 0.00 & 0.00 & 0.00 & 0.00 & 0.00 \\
\hline Sweden & 0.17 & 0.14 & 0.14 & 0.17 & 0.14 & 0.14 & 0.03 & 0.03 & 0.03 \\
\hline United Kingdom & 0.20 & 0.22 & 0.21 & 0.20 & 0.21 & 0.20 & 0.04 & 0.04 & 0.04 \\
\hline Norway & 0.21 & 0.15 & 0.16 & 0.20 & 0.15 & 0.16 & 0.04 & 0.03 & 0.03 \\
\hline Turkey & -0.03 & -0.06 & -0.06 & -0.03 & -0.06 & -0.06 & -0.01 & -0.01 & -0.01 \\
\hline China & 0.13 & 0.13 & 0.15 & 0.11 & 0.12 & 0.13 & 0.02 & 0.02 & 0.03 \\
\hline Japan & 0.15 & 0.12 & 0.14 & 0.14 & 0.12 & 0.13 & 0.03 & 0.02 & 0.03 \\
\hline Korea & 0.32 & 0.28 & 0.31 & 0.30 & 0.27 & 0.29 & 0.06 & 0.05 & 0.06 \\
\hline United States & -0.01 & -0.01 & -0.01 & -0.01 & -0.01 & -0.01 & 0.00 & 0.00 & 0.00 \\
\hline
\end{tabular}

Notes: By construction, total employment does not change in the fixed labour supply scenario.

Source: Own estimations using the GTAP database. 
Table 16: CGE results for the labour market, labour displacement and employment changes for low skill workers in selected sectors, percentage changes

\begin{tabular}{|c|c|c|c|c|c|c|}
\hline & \multicolumn{3}{|c|}{$\begin{array}{c}\text { Labour displacement } \\
\text { flexible labour supply }\end{array}$} & \multicolumn{3}{|c|}{$\begin{array}{l}\text { Sectoral employment changes } \\
\text { low skill, flexible labour supply }\end{array}$} \\
\hline & low skill & medium skill & high skill & Motor vehicles & Metals & Other manuf. \\
\hline Austria & 0.25 & 0.21 & 0.01 & 0.41 & 0.20 & -0.11 \\
\hline Belgium & 0.35 & 0.30 & 0.04 & 0.28 & 0.32 & -0.64 \\
\hline Bulgaria & 0.14 & 0.09 & 0.02 & -0.08 & -0.29 & -0.17 \\
\hline Croatia & 0.08 & 0.07 & 0.01 & -0.19 & -0.03 & -0.12 \\
\hline Czech Republic & 0.21 & 0.17 & 0.03 & 0.10 & 0.23 & -0.27 \\
\hline Denmark & 0.65 & 0.41 & 0.07 & -0.15 & -0.13 & -1.10 \\
\hline Estonia & 0.44 & 0.35 & 0.04 & -0.20 & 0.24 & -0.58 \\
\hline Finland & 0.39 & 0.21 & 0.05 & -0.04 & 0.21 & -0.06 \\
\hline France & 0.14 & 0.10 & 0.01 & -0.15 & -0.02 & -0.19 \\
\hline Germany & 0.35 & 0.25 & 0.03 & 0.54 & 0.29 & -0.77 \\
\hline Greece & 0.07 & 0.04 & 0.00 & -0.14 & -0.08 & -0.10 \\
\hline Hungary & 0.36 & 0.24 & 0.04 & 0.11 & 0.18 & 0.00 \\
\hline Ireland & 0.33 & 0.22 & 0.17 & -0.38 & -0.43 & -0.98 \\
\hline Italy & 0.08 & 0.04 & 0.02 & -0.14 & 0.01 & -0.08 \\
\hline Latvia & 0.74 & 0.44 & 0.05 & 0.00 & 0.26 & -0.48 \\
\hline Lithuania & 0.34 & 0.22 & 0.04 & 0.05 & 0.37 & -0.38 \\
\hline Netherlands & 0.51 & 0.34 & 0.08 & 0.05 & 0.62 & -1.14 \\
\hline Poland & 0.42 & 0.28 & 0.01 & 0.06 & 0.57 & -0.37 \\
\hline Portugal & 0.12 & 0.07 & 0.02 & -0.08 & 0.05 & -0.13 \\
\hline Romania & 0.11 & 0.07 & 0.01 & -0.07 & 0.10 & -0.06 \\
\hline Slovakia & 0.49 & 0.34 & 0.06 & 1.33 & -0.04 & -0.28 \\
\hline Slovenia & 0.19 & 0.16 & 0.01 & -0.11 & 0.10 & -0.10 \\
\hline Spain & 0.12 & 0.06 & 0.02 & -0.21 & -0.01 & -0.10 \\
\hline Sweden & 0.32 & 0.21 & 0.01 & 0.04 & 0.54 & -0.41 \\
\hline United Kingdom & 0.34 & 0.24 & 0.04 & 0.34 & 0.65 & -0.93 \\
\hline Norway & 0.50 & 0.27 & 0.02 & -0.49 & 0.58 & -0.81 \\
\hline Turkey & 0.05 & 0.02 & 0.00 & -0.13 & 0.03 & -0.11 \\
\hline China & 0.13 & 0.10 & 0.01 & -0.53 & -0.09 & 0.21 \\
\hline Japan & 0.17 & 0.08 & 0.01 & 0.09 & 0.01 & -0.08 \\
\hline Korea & 0.21 & 0.17 & 0.01 & -0.05 & -0.21 & -0.07 \\
\hline United States & 0.03 & 0.01 & 0.00 & -0.03 & 0.01 & 0.02 \\
\hline
\end{tabular}


Table 17: CGE results on CO2 emissions for selected countries

\begin{tabular}{|c|c|c|c|c|}
\hline & \multirow{2}{*}{$\begin{array}{l}\mathrm{CO} 2 \\
\text { emission } \\
\text { changes } \\
(\mathrm{MT}) \\
\end{array}$} & \multicolumn{3}{|c|}{ Benchmark } \\
\hline & & $\begin{array}{l}\mathrm{CO} 2 \text { emission } \\
\% \text { changes }\end{array}$ & $\begin{array}{l}\mathrm{CO} 2 \text { levels } \\
\text { (projections } \\
\text { in 2030) }\end{array}$ & $\begin{array}{l}\text { share in } 2030 \\
\text { projections }\end{array}$ \\
\hline Austria & 0.05 & 0.06 & 72 & $0.2 \%$ \\
\hline Belgium & 0.44 & 0.37 & 117 & $0.3 \%$ \\
\hline Bulgaria & -0.01 & -0.02 & 67 & $0.2 \%$ \\
\hline Croatia & -0.01 & -0.03 & 19 & $0.0 \%$ \\
\hline Czech Republic & 0.26 & 0.19 & 132 & $0.3 \%$ \\
\hline Denmark & 0.00 & 0.00 & 77 & $0.2 \%$ \\
\hline Estonia & 0.08 & 0.40 & 21 & $0.0 \%$ \\
\hline Finland & 0.01 & 0.01 & 60 & $0.1 \%$ \\
\hline France & 0.13 & 0.03 & 413 & $1.0 \%$ \\
\hline Germany & 0.93 & 0.14 & 685 & $1.6 \%$ \\
\hline Greece & -0.08 & -0.04 & 207 & $0.5 \%$ \\
\hline Hungary & -0.03 & -0.07 & 48 & $0.1 \%$ \\
\hline Ireland & 0.08 & 0.15 & 52 & $0.1 \%$ \\
\hline Italy & -0.17 & -0.04 & 403 & $0.9 \%$ \\
\hline Latvia & 0.03 & 0.23 & 13 & $0.0 \%$ \\
\hline Lithuania & 0.01 & 0.11 & 14 & $0.0 \%$ \\
\hline Netherlands & 0.32 & 0.17 & 190 & $0.4 \%$ \\
\hline Poland & 0.49 & 0.14 & 359 & $0.8 \%$ \\
\hline Portugal & -0.02 & -0.03 & 57 & $0.1 \%$ \\
\hline Romania & -0.03 & -0.03 & 98 & $0.2 \%$ \\
\hline Slovakia & 0.10 & 0.27 & 37 & $0.1 \%$ \\
\hline Slovenia & -0.02 & -0.09 & 18 & $0.0 \%$ \\
\hline Spain & -0.07 & -0.02 & 303 & $0.7 \%$ \\
\hline Sweden & 0.06 & 0.10 & 56 & $0.1 \%$ \\
\hline United Kingdom & 1.01 & 0.19 & 522 & $1.2 \%$ \\
\hline Norway & 0.00 & 0.00 & 75 & $0.2 \%$ \\
\hline Turkey & -0.19 & -0.04 & 441 & $1.0 \%$ \\
\hline China & 12.13 & 0.09 & 13,055 & $30.7 \%$ \\
\hline Japan & 0.68 & 0.07 & 1,039 & $2.4 \%$ \\
\hline Korea & 0.69 & 0.11 & 658 & $1.5 \%$ \\
\hline United States & -0.63 & -0.01 & 6,052 & $14.2 \%$ \\
\hline Total (World) & 14.23 & 0.06 & 25,361 & $100.0 \%$ \\
\hline
\end{tabular}

Source: Own estimations using the GTAP database. 
Publisher:

CPB Netherlands Bureau for Economic Policy Analysis

P.O. Box $80510 \mid 2508$ GM The Hague

$\mathrm{T}(\mathbf{0 7 0 )} 3383380$

May 2015 | ISBN 978-90-5833-690-3 